\title{
Combined effects of an antifouling biocide and nutrient status on a shallow-water microbenthic community
}

\author{
Fredrik Larson $^{1, *}$, Dorthe G. Petersen ${ }^{1,2}$, Ingela Dahllöf ${ }^{2}$, Kristina Sundbäck ${ }^{1}$ \\ ${ }^{1}$ Department of Marine Ecology, Marine botany, Göteborg University, PO Box 461, 40530 Göteborg, Sweden \\ ${ }^{2}$ Department of Marine Ecology, National Environmental Research Institute, Frederiksborgvej 399, 4000 Roskilde, Denmark
}

\begin{abstract}
The complex systems of shallow-water sediments are today subjected to varying nutrient inputs combined with other anthropogenic stressors, such as toxicants. The effects of differences in nutrient status of the sediment combined with short-term, low-level exposure to the anti-fouling biocide copper pyrithione (CPT) were studied in a $38 \mathrm{~d}$ experiment using intact sediment in a flowthrough mesocosm system. Abundance and diversity of microphytobenthos, bacteria and meiofauna were assessed together with sediment-water oxygen and nutrient fluxes (day and night) and denitrification. More effects were found for the sediment with higher nutrient status, but these combined effects could not be predicted by adding the separate effects of nutrients and CPT observed for the sediment with low nutrient status. Biomass and diversity of microphytobenthos increased later on in the experiment due to CPT exposure, as did bacterial activity and abundance. CPT exposure also increased the proportion of nematodes in the meiofauna. Generally, prokaryotic functions appeared more affected by CPT exposure than eukaryotic. Differences in the response of functional variables suggest that eukaryotic photoautotrophs possess a higher functional redundancy than heterotrophs. Among nutrient fluxes the nitrogen cycling was affected through changed rates of ammonium flux and denitrification. The integrated analyses show a clearer effect of CPT on the community structure under low-nutrient status, while CPT affected the community function more in the high-nutrient system. All treatments show convergence of function, in both light and dark, towards the end of the experiment, whereas the structure remained separated due to the nutrient regime.
\end{abstract}

KEY WORDS: Combined stressors $\cdot$ Sediment $\cdot$ Eutrophication $\cdot$ Copper pyrithione $\cdot$ Nutrient cycling $\cdot$ Microphytobenthos $\cdot$ Bacteria $\cdot$ Meiofauna

\section{INTRODUCTION}

The most common way to test toxicity to date has been through laboratory studies with 1 or several species exposed to 1 stressor at a time under constant conditions (Nacci et al. 1986, Haglund 1997). These types of tests are difficult to extrapolate to natural field conditions since they exclude a large number of potential interactions that occur among the numerous components of complex natural ecosystems, so-called indirect effects (Brock et al. 2004). This also implies that simple laboratory experiments ignore interactions between stressors that act simultaneously upon the system.
Experiments in which stressors are combined and studied in natural systems close to field conditions will therefore produce data that, to a higher degree, reflect the impact on natural systems; this increases the relevance of the results for system modelling and risk assessment in coastal management (Breitburg et al. 1999, Lenihan et al. 2003, Wiegner et al. 2003). The advantages of - and large need for-experiments designed with multiple stressors acting upon natural or semi-natural systems have been recognised in several reviews (Heugens et al. 2001, Koelmans et al. 2001, Fleeger et al. 2003). Studies on multiple stressors have shown that several differences in both direct and indi- 
rect effects occur when the stressors are combined compared to when acting alone (Skei et al. 2000, Laursen et al. 2002, Millward et al. 2004). Interactions between stressors in a system might cause non-additive effects, giving a totally different response than what would have been the case assuming simple additive effects (Folt et al. 1999).

Cloern (2001) has reviewed and described the conceptual models of coastal eutrophication, which include 3 phases. The first 2 phases are fairly simple, and include only the signal of nutrient enrichment and the responses to enrichment. These 2 are relatively well investigated. In the third phase, other stressorsincluding toxicants - are added in combination with nutrient enrichment. This third phase is at present not well studied, and we hope that the present study can contribute information suitable to represent the third phase in a conceptual model.

In the present experiment we studied the combined effects of eutrophication and the anti-fouling biocide copper pyrithione (CPT) on natural sediment communities from a shallow-water marine area. These areas are very important nurseries for fish, and, because of the presence of highly productive primary producers, they also function as nutrient filters between terrestrial and marine ecosystems (Nielsen et al. 2004). Increased knowledge about the sensitivity and direct and indirect effects from disturbances are therefore important for the management of these areas, aiming at a sustainable use of their resources. Shallow-water sediment systems close to populated areas are subject to a wide range of disturbances coupled to anthropogenic activities, and anti-fouling biocides - such as CPTare likely to be present due to near-shore boating activities. Combinations of the presence of CPT and differences in the nutrient status are of interest, since the nutrient load can vary greatly in areas potentially subjected to CPT. A particular combination of CPT and nutrients has previously been studied by Maraldo \& Dahllöf (2004b), and a relationship between toxicity to planktonic communities and the level of phosphate in the water column was found.

CPT is not commonly used in anti-fouling paints in Europe, whereas the related compound zinc pyrithione (ZPT) is widely applied. However, when ZPT is released into the environment, it is trans-chelated into CPT, which implies that CPT is present in the European environment (Grunnet \& Dahllöf 2005). Singlespecies tests have shown toxic effects of CPT on, e.g., algae and larvae of crustaceans and mussels (Faimali et al. 2003), sea urchin eggs and embryos (Kobayashi \& Okamura 2002) and fish cells (Okamura et al. 2002), as have tests using marine bacterial and algal communities (Maraldo \& Dahllöf 2004b, Petersen et al. 2004, Hjorth et al. 2006).
The aim of the present experiment was to study the effects of short-term, low-level exposure to CPT on both the auto- and heterotrophic components of a natural sediment community under 2 different nutrient regimes. In order to separate the effects according to auto- and heterotrophic processes, measurements of oxygen and nutrient fluxes were made in both the light and dark. In order to examine indirect effects, the system was studied during a period of $38 \mathrm{~d}$ after CPT exposure. The present study focuses on effects on the function (oxygen and nutrient fluxes) and structure of microorganism groups such as benthic algae (microphytobenthos), bacteria and meiofauna. Microorganisms largely drive central processes in the sediment (primary production, decomposition, nutrient turnover). Effects on system-level variables (trophic state, retention and removal of nitrogen) are described and interpreted in Sundbäck et al. (2007).

\section{MATERIALS AND METHODS}

General approach. The initial manipulations of nutrient enrichment and CPT additions were done on intact undisturbed sediment in cylinders (inner diameter $25 \mathrm{~cm}$ ) that were randomly placed in a flowthrough mesocosm system, with a total of 48 sediment cylinders. Prior to toxicant addition and sampling, half of the cylinders were enriched with nutrients $\left(\mathrm{NH}_{4}{ }^{+}\right.$, $\mathrm{NO}_{3}{ }^{-}$and $\mathrm{PO}_{4}{ }^{3-}$ ) for $14 \mathrm{~d}$. CPT was added to 12 nutrient-enriched and 12 non-enriched cylinders for 4 consecutive nights to minimise its degradation by light exposure (Maraldo \& Dahllöf 2004a). The 4 treatments were: low-nutrient level $\left(\mathrm{Nu}_{\text {low }}\right)$, high-nutrient level $\left(\mathrm{Nu}_{\text {high }}\right)$, low-nutrient level and $\mathrm{CPT}\left(\mathrm{Nu}_{\text {low }} \mathrm{CPT}\right)$, and high-nutrient level and $\mathrm{CPT}\left(\mathrm{Nu}_{\text {high }} \mathrm{CPT}\right)$. The responses of the community structure and functions to CPT were followed through sampling of 3 replicate cylinders from each treatment on 7 occasions for $38 \mathrm{~d}$ (9 September to 17 October 2002) after the manipulation period, of which 3 included fluxes only and 4 included all structural and functional variables. Functional variables included day-time and night-time measurements of oxygen and nutrient fluxes $\left[\mathrm{NH}_{4}{ }^{+}\right.$, $\left.\mathrm{NO}_{3}{ }^{-}+\mathrm{NO}_{2}{ }^{-}, \mathrm{PO}_{4}{ }^{3-}, \mathrm{Si}(\mathrm{OH})_{4}\right]$ and dark measurements of denitrification and bacterial production. Structural variables included the amount of chlorophyll a (chl a), abundance and diversity of microphytobenthos, bacteria and meiofauna. Abundance of macroscopic infauna was also assessed.

Sediment collection. The sediment was collected from a boat with an Olausson box-corer $(30 \mathrm{~cm} \times$ $30 \mathrm{~cm}$ ) at a depth of 3 to $4 \mathrm{~m}$, in the Bay of Munkeby $\left(58^{\circ} 14^{\prime} \mathrm{N}, 11^{\circ} 32^{\prime} \mathrm{E}\right)$ in a sound connecting the Gullmar and Koljö Fjords on the Swedish west coast. This 
area is microtidal, with a maximum tidal amplitude of $30 \mathrm{~cm}$. When the sediment core was on deck, a cylinder of black ABS plastics with a height and inner diameter of $25 \mathrm{~cm}$ was lowered gently into the sediment until there was about $10 \mathrm{~cm}$ left at the cylinder top. A marine plywood plate was inserted from the side to function as a bottom for the sediment in the cylinder. The sediment was silty sand, with a porosity of 0.85 and an organic content of approximately $10 \%$.

Experimental set-up. The experiment was run in a mesocosm system at Kristineberg Marine Research Station near the Gullmar Fjord. The system consisted of a greenhouse from which the walls had been removed. This set-up allowed natural light and temperature conditions and protected the system against precipitation. In the mesocosm system, the 48 cylinders were positioned randomly and supplied with unfiltered water from $4 \mathrm{~m}$ depth of the Gullmar Fjord (salinity: 26 to 29). The incoming water was led to an elevated water container of $300 \mathrm{l}$ from which it flowed into $10 \mathrm{~mm}$ tubing by self-pressure to 8 tubes $(100 \mathrm{~cm} \times 10 \mathrm{~cm})$ each of which had 6 outlets $(6 \mathrm{~mm})$. These outlets led to inlets $(4 \mathrm{~mm})$ placed $5 \mathrm{~cm}$ from the upper rim of each cylinder, resulting in a flow of $\sim 10 \mathrm{l} \mathrm{h}^{-1}$. The overlying water depth was $\sim 10 \mathrm{~cm}$, leading to a total water volume of $5 \mathrm{l}$.

Filamentous green algae belonging to the genus Ulva (formerly Enteromorpha) that started to grow on the cylinder walls were regularly removed in order to avoid their influence on net fluxes from the sediment system. Furthermore, visible macrofauna, e.g. snails, brittlestars and settled mussels, were removed from the top of the sediment and cylinder walls.

Nutrient enrichment. For the nutrient addition, a continuous in situ supply method used by Hillebrand \& Kahlert (2002) was applied. Granules of a commercial fertiliser $\left(\mathrm{NH}_{4}{ }^{+}, \mathrm{NO}_{3}{ }^{-}\right.$and $\left.\mathrm{PO}_{4}{ }^{3-}\right)$ were placed in mesh bags at the water inlet of 24 experimental cylinders. The fertiliser used was Hydro Agri OptiCrop NPK 213-10, which consists of non-coated granules, and is commonly used in agriculture on lea and pasture ground. The amount of granules in the bag for each cylinder was $10 \mathrm{~g}$, equal to $126 \mathrm{~g} \mathrm{~N} \mathrm{~m}^{-2}$ and $18 \mathrm{~g} \mathrm{P} \mathrm{m}^{-2}$. This addition was chosen according to suggestions by Williams \& Ruckelshaus (1993), reviewed by Worm et al. (2000). Because of the wash-out by the flowthrough water, the bags were replaced 3 times during the $14 \mathrm{~d}$ of addition, to maintain a stable supply. Average levels of $\mathrm{NH}_{4}{ }^{+}(250 \mu \mathrm{M}), \mathrm{NO}_{3}{ }^{-}(150 \mu \mathrm{M})$ and $\mathrm{PO}_{4}{ }^{3-}$ $(50 \mu \mathrm{M})$ were measured in the overlying water during the enrichment period.

Toxicant. CPT was added to half of the cylinders (12 $\mathrm{Nu}_{\text {high }}$ and $12 \mathrm{Nu}_{\text {low }}$ ) as sediment-toxicant slurries, where dimethylsulfoxide (DMSO) was used as solvent. Before the slurry was added, the water flow was stopped and the water level lowered to the level of the inlet, to ensure that the toxicant would reach the sediment. The same slurry with DMSO, but without CPT, was added to the controls, $\mathrm{Nu}_{\text {low }}$ and $\mathrm{Nu}_{\text {high }}$. This minimal deposition was just a powdering on the surface and gave no covering layer. CPT is photosensitive and degrades in daylight with a degradation time of approximately 7 min (Maraldo \& Dahllöf 2004a). Addition was done during 4 nights, as the degradation time is significantly reduced at low light intensities and is negligible in the dark (Grunnet \& Dahllöf 2005). This gave a final concentration of $1 \mathrm{nmol} \mathrm{g}^{-1}$ dry sediment in the top $5 \mathrm{~cm}$, where most bioturbation occurs. This concentration range equalled the LOECs (lowest observed effect concentrations) found in a microcosm study with sieved sediment (Petersen et al. 2004).

Sampling and analysis. Oxygen and nutrient fluxes: Fluxes were measured in 12 of the cylinders at each sampling, by incubation under lid without water flow. The overlying water was stirred by a Teflon-coated stirring bar hanging in the lid. The stirring bar was turned by a large external u-magnet, driven by an electrical engine. At the beginning of the incubation, samples were taken for oxygen and nutrient levels. The time for incubation was set so that oxygen concentration should not increase or decrease by $>20 \%$, in order to avoid interferences with nutrient fluxes caused by larger changes in oxygen concentrations (Dalsgaard et al. 2000). The incubation time averaged just over $1 \mathrm{~h}$ in the light and about $2 \mathrm{~h}$ in the dark. Light incubations were done during the day between $\sim 12: 00$ and 13:00 $\mathrm{h}$, and the dark incubations were done at night-time between 00:00 and 02:00 h. Oxygen samples were analysed immediately after sampling, using the Winkler technique (Strickland \& Parsons 1972). Nutrient samples were filtered (Sartorius $0.45 \mu \mathrm{m}$ syringe filters) and frozen $\left(-20^{\circ} \mathrm{C}\right)$ prior to analysis. Ammonium $\left(\mathrm{NH}_{4}^{+}\right)$, nitrate + nitrite $\left(\mathrm{NO}_{3}{ }^{-}+\mathrm{NO}_{2}{ }^{-}\right)$, phosphate $\left(\mathrm{PO}_{4}{ }^{3-}\right)$ and silicate $\left[\mathrm{Si}(\mathrm{OH})_{4}\right]$ were analysed by wet-chemistry methods with a SCAN ${ }^{\text {PLUS }}$ System Scalar auto-analyzer (SCALAR) at the National Environmental Research Institute (NERI), Roskilde, Denmark.

Denitrification: Dark incubations for denitrification were carried out with the ${ }^{15} \mathrm{~N}$-isotope pairing technique (Nielsen 1992) by inserting small Plexiglas cylinders (inner diameter: $3.5 \mathrm{~cm}$; height: $25 \mathrm{~cm}$ ) into the sediment. The incubations were done subsequent to the flux measurements in the dark. After taking initial nutrient samples from the denitrification cores, $1 \mathrm{ml}$ of $10 \mathrm{mM}^{15} \mathrm{NO}_{3}{ }^{-}$(99.6 at. \%, Europa Scientific) was added to give a $\mathrm{NO}_{3}{ }^{-}$concentration corresponding to $\sim 30 \%$ of the oxygen concentration. The label was allowed to diffuse into the sediment $(0.5 \mathrm{~h})$ after which new samples for nutrients were taken, in order to get the real starting concentration of ${ }^{15} \mathrm{NO}_{3}{ }^{-}$. The cylinders were closed with tightly fitting Plexiglas plugs and incu- 
bated for approximately $2 \mathrm{~h}$. The overlying water column was stirred during the incubations by a small hang-mounted Teflon stirring bar, driven in the same way as the stirring in the full cylinder oxygen-nutrient fluxes. To terminate the incubation, $0.5 \mathrm{ml}\left(1 \mathrm{~g} \mathrm{ml}^{-1}\right)$ of zinc-chloride $\left(\mathrm{ZnCl}_{2}\right)$ was added and the sediment was slurred with the overlying water. Slurry samples were transferred into $12 \mathrm{ml}$ gas-tight vials, extra $\mathrm{ZnCl}_{2}$ $(0.25 \mathrm{ml})$ was added, and the vials were tightly closed and stored in a refrigerator until analysis. Produced ${ }^{29} \mathrm{~N}_{2}$ and ${ }^{30} \mathrm{~N}_{2}$ were analysed with GC-MS (gas chromatography-mass spectrometry) at NERI. Calculations of total denitrification $\left(D_{\text {tot }}\right)$ were done according to Dalsgaard et al. (2000).

Chl a: Samples for chl a content in the sediment were taken with a cut-off $2 \mathrm{ml}$ syringe from the top $5 \mathrm{~mm}$ of the sediment, pooling 5 sub-samples from each replicate cylinder. Chl a was extracted in $3 \mathrm{ml}$ of $90 \%$ acetone, sonicated (10 $\mathrm{min}$ ) in an ice-bath and stored cold and dark for $24 \mathrm{~h}$. The samples were centrifuged for $10 \mathrm{~min}$, and the absorbance of the supernatant was analysed with a spectrophotometer (Shimadzu UV 2401-PC). Chl a and phaeopigment concentrations were calculated according to Lorenzen (1967).

Microphytobenthos: Samples for algal diversity were taken as described for chl $a$, preserved with glutharaldehyde (final concentration $2.5 \%$ ) and stored in a refrigerator. The algae were counted and classified to species, genera and/or size class in an epifluorescence microscope at $500 \times$ magnification. A minimum of 200 cells per sample were counted, and 30 algae of each group were measured to calculate cell volume using geometric formulae (for details see Sundbäck \& Snoejs 1991). The microphytobenthic composition, and relative (\%) biovolume, was analysed only for Days 1 and 24. Diversity was calculated as the Shannon-Weaver index, $H^{\prime}=\Sigma-p(\ln p)$ (Shannon \& Weaver 1949), where $p$ is the fraction of each taxonomic unit in the total number of cells.

Fauna: Samples for meiofauna were taken with a cut-off $20 \mathrm{ml}$ syringe from the top $5 \mathrm{~mm}$ of the sediment, pooling 3 sub-samples from each cylinder. Formalin (4\%) containing Rose Bengal was added for conservation and colouration of the fauna. The organisms were extracted by decantation and collected on a $100 \mu \mathrm{m}$ sieve, counted and allocated to major phylogenetic groups under a dissection microscope.

Macroscopic infauna was collected after the destructive sampling by sieving the total amount of sediment in each cylinder through a $1 \mathrm{~mm}$ sieve, and then classified to genera or species.

Bacterial production: Bacterial production was estimated by incorporation of ${ }^{14} \mathrm{C}$ leucine into bacterial proteins according to Petersen et al. (2004). Five subsamples (each approximately $0.2 \mathrm{~g}$ of sediment) from each cylinder were incubated with $200 \mu$ of $5 \mu \mathrm{M}{ }^{14} \mathrm{C}$ leucine for $1 \mathrm{~h}$ at $15^{\circ} \mathrm{C}$ in the dark. The incubation was terminated by adding $20 \mu \mathrm{l}$ formalin, and the proteins were extracted from the bacteria and sediment into a buffer consisting of TE buffer and sodium lauryl sulphate $(3 \%)$ using bead beating. The proteins were precipitated with trichloroacetic acid $\left(\mathrm{CCl}_{3} \mathrm{COOH}\right)$, and skimmed milk was added to enhance the precipitation. The radioactive decay was measured directly in the Eppendorf tubes on a Beckman LS 1801 scintillation counter. Specific bacterial production was calculated by dividing the bacterial production with the number of 16S rRNA gene copies (see below).

Bacterial abundance: Five sub-samples ( 0.2 g sam$\mathrm{ple}^{-1}$ ) were taken from each cylinder, and DNA was extracted by bead beating according to Petersen et al. (2004). During the DNA extraction, internal standards were used to compensate for experimental variability (Petersen \& Dahllöf 2005a). The number of bacterial 16S rRNA gene copies (Eubacteria) was used as a proxy for bacterial abundance using real-time quantitative PCR (polymerase chain reaction) according to Skovhus et al. (2004).

Bacterial diversity: The bacterial diversity was analysed with PCR-DGGE, and a fragment of the gene coding for the RNA polymerase beta sub-unit (rpoB) was amplified for subsequent DGGE analysis using the primers rpoB1698F (5'-AACATCGGTTTGATCAAC-3') and rpoB2041R (5'-CGTTGCATGTTGGTACCCAT-3'). A GC-clamp was added to the forward primer at the 5' end (5'-CGCCCCCCGCGCCCCGCGCCCGGCCCGCCGCCCCCGCCCC-3'). One of the advantages of using the $r p o B$ gene in bacterial diversity analysis is that the gene is only found in a single copy, in contrast to possible multiple copies of the 16S rDNA. Furthermore, the $r p o B$ gene possesses the same key attributes as $16 \mathrm{~S}$ rDNA, e.g. it is common in all bacteria and it contains conserved as well as variable regions and therefore can be used as a phylogenetic marker (Dahllöf et al. 2000). PCR reaction mixtures $(20 \mu \mathrm{l})$ contained $2 \mu \mathrm{l}$ of PCR buffer, $0.5 \mu \mathrm{l}$ of dNTP (deoxyribonucleotide triphosphate; $20 \mathrm{pmol} \mathrm{\mu l}^{-1}$ of each), $0.5 \mu$ l of forward and reverse primer $\left(25\right.$ pmol $\mu^{-1}$ ), $0.5 \mu$ l BSA (bovine serum albumin; $10 \mathrm{mg} \mathrm{ml}^{-1}$ ), $13 \mu \mathrm{l}$ Milli-Q water, $1 \mu \mathrm{l}$ JumpStart RedTaq polymerase and $2 \mu \mathrm{l}$ of sample DNA (50 ng $\mathrm{ul}^{-1}$ ). The following programme was used: 5 min at $94^{\circ} \mathrm{C}$; amplification for 25 cycles, consisting of denaturing for $30 \mathrm{~s}$ at $94^{\circ} \mathrm{C}$, annealing for $1 \mathrm{~min}$ a $50^{\circ} \mathrm{C}$ and extension for $1.5 \mathrm{~min}$ at $72^{\circ} \mathrm{C}$, and a final extension of $10 \mathrm{~min}$ at $72^{\circ} \mathrm{C}$ (Hybaid PCR Express Thermal Cycling machine, Franklin). Primers were supplied by DNA Technology A/S, dNTPs were supplied by Invitrogen, PCR buffer and JumpStart RedTaq polymerase were supplied by Sigma. The PCR products were run on a DGGE gel with a gradient of polyacrylamide (6 to 
$8 \%$ ) parallel to a 35 to $55 \%$ linear denaturant gradient (100\% denaturing gradient contains $7 \mathrm{M}$ urea and $40 \mathrm{ml}$ of formamide $100 \mathrm{ml}^{-1}$ ). Electrophoresis was run for $16 \mathrm{~h}$ at $75 \mathrm{~V}$ using the Biorad D-code system (Hercules) in $0.5 \times$ TAE buffer. The gels were stained with SYBR Gold (Molecular Probes) in 1× TAE buffer $(1: 10000)$ and analysed in KODAK 1D Image Analysis Software. During the PCR and DGGE, internal standards, were added in order to compensate for experimental variability (Petersen \& Dahllöf 2005b).

Statistical analysis. Two-way ANOVA, with time and treatment as fixed factors, was used to test for significant effects, and when there was a significant interaction between factors, pair-wise comparisons of the means were made by the post-hoc SNK (StudentNewman-Keuls) test. In cases with non-significant 2-way ANOVA, 1-way ANOVA was used to test for significance on single days. All variables were tested for effects of the initial nutrient enrichment (Table 1) and of CPT effects at the 2 different nutrient levels (Table 2). All ANOVA tests were run in SPSS v.12.0.1. Significance levels for individual variables are given in the text.

Two-way permutational multivariate analysis of variance (PERMANOVA) (Anderson 2001, McArdle \& Anderson 2001), with the fixed factors treatment and day, was used to analyse microalgal composition and the integrated community structure and function. Permutation implies random re-assignment of the observations to the treatment groups under each variable, with subsequent re-calculation of the F-statistics. This is repeated many times in order to create a distribution of $F$-values, which then is used for comparison with the Fvalue from the original data set instead of tabulated values. The data matrix for microalgal composition included the relative abundance of each of the 47 found taxonomic units in the 4 treatments on Days 1 and 24. The algal raw data were neither transformed nor standardised, and the analysis was based on the measure of Bray-Curtis dissimilarities.

The data matrix for the analysis of integrated community structure included the variables chl a, meiofaunal abundance, number of $16 \mathrm{~S}$ gene copies, sediment content of total DNA, and organic carbon and organic nitrogen content on 4 occasions (Days 1, 9, 24 and 38). The analyses of community function were based on data matrices from dark and light measurements, respectively, of the fluxes of oxygen and nutrients $\left[\mathrm{NH}_{4}{ }^{+}, \mathrm{NO}_{3}{ }^{-}+\mathrm{NO}_{2}{ }^{-}, \mathrm{PO}_{4}{ }^{3-}, \mathrm{Si}(\mathrm{OH})_{4}\right]$ on 7 occasions (Days 1, 3, 9, 16, 24, 31 and 38). The raw data matrices for integrated community structure and function were not transformed, but standardised to $z$ scores (normalised). These analyses were based on Euclidean distances. For the community function, the tests were run on data matrices from the light and the dark sampling, separately. A total of 9999 permutations of raw data were used in all tests. To find out when the CPT treatments $\left(\mathrm{Nu}_{\text {low }} \mathrm{CPT}\right.$ and $\left.\mathrm{Nu}_{\text {high }} \mathrm{CPT}\right)$ were inseparable from their respective controls $\left(\mathrm{Nu}_{\text {low }} \& \mathrm{Nu}_{\text {high }}\right)$, a posteriori pair-wise comparisons were done with the factor treatment under each level of the factor day. After the PERMANOVA, tests of permutational multivariate dispersion (PERMDISP) were run on the same data matrices to find differences in within-group dispersion based on replicate distance to the group centroid. Principal coordinate (PCO) analysis was calculated from the data matrices and plotted for the 2 axes describing the greatest percentage of the variation. The multivariate analysis was run using the programs PERMANOVA v.1.6 (Anderson 2001, 2005, McArdle \& Anderson 2001), PERMDISP (Anderson 2004) and PCO3 (Anderson 2003).

Table 1. Significance (2-way ANOVA) of the effects from the initial $14 \mathrm{~d}$ nutrient addition $\left(\mathrm{Nu}_{\text {low }}\right.$ vs. $\mathrm{Nu}_{\text {high }}$ : low- and high-nutrient level, respectively) on functional (light and dark) and structural variables. Factors used were day (D) and nutrient $(\mathrm{Nu})$ treatment $(\mathrm{T})$. T: single main factor effect of $\mathrm{Nu}$; $\mathrm{D} \times \mathrm{T}$ : significant interaction between factors $(\mathrm{p}<0.05$ are shown in bold and $\mathrm{p}<0.1$ in plain print); NS: no significant effect revealed by 2-way ANOVA $(p>0.1)$. Significant on day: day(s) on which the effect was significant based on either Student-Newman-Keul's (SNK) test or 1-way ANOVA (the latter denoted by asterisk)

\begin{tabular}{|c|c|c|c|}
\hline Variable & Factor & $\mathrm{p}$ & Significant on day \\
\hline \multicolumn{4}{|l|}{ Functional variables } \\
\hline \multicolumn{4}{|l|}{ Light } \\
\hline Net oxygen production & $\mathrm{T}$ & 0.07 & \\
\hline Chl a normalised algal product & & NS & $9^{*}$ \\
\hline Ammonium flux & $\mathrm{T}$ & 0.08 & $1^{*}, 38^{*}$ \\
\hline Nitrate flux & $\mathbf{T}$ & 0.03 & $\mathbf{1}^{*}, 24^{*}$ \\
\hline Phosphate flux & $\mathbf{T}$ & 0.001 & $\mathbf{1}^{*}, \mathbf{1 6}^{*}, 24^{*}, \mathbf{3 1} 1^{*}$ \\
\hline Silicate flux & & NS & $3^{*}$ \\
\hline \multicolumn{4}{|l|}{ Dark } \\
\hline Oxygen consumption & $\mathbf{T}$ & 0.03 & $\mathbf{1}^{*}, 38^{*}$ \\
\hline Ammonium flux & & NS & $\mathbf{9}^{*}, 38^{*}$ \\
\hline Nitrate flux & $\mathbf{D} \times \mathbf{T}$ & 0.008 & 3,16 \\
\hline Phosphate flux & $\mathbf{D} \times \mathbf{T}$ & 0.0001 & $1,3,9,16,24,31$ \\
\hline Silicate flux & & NS & \\
\hline Total denitrification & $\mathbf{D} \times \mathbf{T}$ & 0.04 & 1,38 \\
\hline Bacterial production & & NS & \\
\hline Specific bacterial production & $\mathrm{T}$ & 0.09 & \\
\hline \multicolumn{4}{|l|}{ Structural variables } \\
\hline Chl a & $\mathbf{T}$ & 0.006 & $9^{*}, 38^{*}$ \\
\hline Algal cell volume & $\mathbf{T}$ & 0.04 & \\
\hline Algal diversity & & NS & $24^{*}$ \\
\hline Bacterial abundance & $\mathbf{T}$ & 0.01 & $9^{*}, 38^{*}$ \\
\hline Meiofaunal density & $\mathrm{D} \times \mathrm{T}$ & 0.08 & $1^{*}$ \\
\hline Meiofaunal diversity & $\mathrm{T}$ & 0.09 & $24^{*}$ \\
\hline
\end{tabular}


Table 2. Significance (2-way ANOVA) of the effects of copper pyrithione (CPT) addition on functional (light and dark) and structural variables in the $\mathrm{Nu}_{\text {low }}$ and $\mathrm{Nu}_{\text {high }}$ systems. Factors used were day (D) and CPT treatment (T). T: single main factor effect of $\mathrm{CPT}$; $\mathrm{D} \times \mathrm{T}$ : significant interaction between factors $(\mathrm{p}<0.05$ are shown in bold, and $\mathrm{p}<0.1$ in plain print); NS: no significant effect revealed by 2-way ANOVA ( $p>0.1$ ). Significant on day: the day(s) on which the effect was significant based on either StudentNewman-Keul's (SNK) test or 1-way ANOVA (the latter denoted by asterisk)

\begin{tabular}{|c|c|c|c|c|c|c|}
\hline \multirow[t]{2}{*}{ Variable } & \multirow{2}{*}{ Factor } & \multicolumn{2}{|c|}{$-\mathrm{Nu}_{\mathrm{low}}-$} & \multirow[b]{2}{*}{ Factor } & \multirow{2}{*}{${ }_{\mathrm{p}} \mathrm{Nu}_{\mathrm{r}}$} & \multirow{2}{*}{ Sh } \\
\hline & & $\mathrm{p}$ & Significant on day & & & \\
\hline \multicolumn{7}{|l|}{ Functional variables } \\
\hline \multicolumn{7}{|l|}{ Light } \\
\hline Net oxygen production & & NS & $24^{*}$ & & & $31^{*}$ \\
\hline Chl a normalised algal production & & NS & $24^{*}$ & & & \\
\hline Ammonium flux & & NS & & $\mathrm{D} \times \mathrm{T}$ & 0.07 & $16^{*}, 24^{*}$ \\
\hline Nitrate flux & & NS & $24^{*}$ & $\mathrm{~T}$ & 0.09 & $3^{*}$ \\
\hline Phosphate flux & & NS & & $\mathbf{D} \times \mathbf{T}$ & 0.001 & $3,9,31$ \\
\hline Silicate flux & & NS & & $\mathbf{D} \times \mathbf{T}$ & 0.02 & $9,16,24$ \\
\hline \multicolumn{7}{|l|}{ Dark } \\
\hline Oxygen consumption & $\mathbf{D} \times \mathbf{T}$ & 0.003 & $1,3,9$ & $\mathrm{D} \times \mathrm{T}$ & 0.09 & $1^{*}, 24^{*}, 31^{*}$ \\
\hline Ammonium flux & & NS & & $\mathbf{D} \times \mathbf{T}$ & 0.008 & $1, \mathbf{9}, 16$ \\
\hline Nitrate flux & $\mathbf{D} \times \mathbf{T}$ & 0.011 & 9,38 & & NS & $9^{*}, 16^{*}$ \\
\hline Phosphate flux & & NS & & $\mathbf{D} \times \mathbf{T}$ & 0.04 & 3,9 \\
\hline Silicate flux & $\mathbf{D} \times \mathbf{T}$ & 0.006 & $3,9,16$ & & NS & $16^{*}$ \\
\hline Total denitrification & $\mathrm{D} \times \mathrm{T}$ & 0.05 & $1^{*}$ & $\mathbf{T}$ & 0.001 & $1^{*}, 24^{*}, 38^{*}$ \\
\hline Bacterial production & & NS & $38^{*}$ & $\mathbf{D} \times \mathbf{T}$ & 0.04 & 9,24 \\
\hline Specific bacterial production & & NS & $38^{*}$ & $\mathbf{D} \times \mathbf{T}$ & 0.004 & $1,24,38$ \\
\hline \multicolumn{7}{|l|}{ Structural variables } \\
\hline Chl a & & NS & $24^{*}$ & & NS & $24^{*}$ \\
\hline Chl a:phaeopigments & & NS & & & NS & $1^{*}, 9^{*}$ \\
\hline Algal cell volume & & NS & & $\mathbf{D} \times \mathbf{T}$ & 0.0001 & 24 \\
\hline Algal diversity & & NS & $24^{*}$ & $\mathrm{D} \times \mathrm{T}$ & 0.07 & $24^{*}$ \\
\hline Bacterial abundance & $\mathrm{T}$ & 0.09 & $9^{*}$ & $\mathrm{~T}$ & 0.10 & \\
\hline Meiofaunal density & & NS & & & NS & $24^{*}$ \\
\hline Meiofaunal diversity & & NS & & & NS & \\
\hline
\end{tabular}

\section{RESULTS}

The initial enrichment period of $2 \mathrm{wk}$, aiming at creating 2 control systems of different nutrient status, resulted in 7 significant differences in both structural and functional variables on Day 1 (Table 1). In the following we define the initial effects of CPT as the effects occurring on Day 1 of measuring, which was $3.5 \mathrm{~d}$ after the first addition of CPT and $0.5 \mathrm{~d}$ after the last addition. This implies that the initial effects most probably represent a mixture of direct and indirect effects (Table 2), and that some observations of direct effects were lost.

\section{Effects of nutrients and CPT on community structure}

Microalgae

Well-developed diatom mats were seen in the $\mathrm{Nu}_{\text {high }}$ system, which was in accordance with a higher chl a content $(p<0.01)$ in the $\mathrm{Nu}_{\text {high }}$ cylinders when compared with $\mathrm{Nu}_{\text {low }}$ cylinders (Fig. 1a,b, Day 1). Microphytobenthos also showed a trend towards species with larger cell volume in the $\mathrm{Nu}_{\text {high }}$ systems (ANOVA $p=0.12$; Fig. 1c,d, Day 1); the nutrient enrichment stimulated particularly the growth of the diatom Entemoneis cf. pseudoduplex, which accounted for, on average, $28 \%$ of the biovolume in the $\mathrm{Nu}_{\text {high }}$ but only $3 \%$ in the $\mathrm{Nu}_{\text {low }}$ system. There was, however, no initial difference in the diversity of microphytobenthos due to the enrichment (Fig. 1e,f, Day 1). Some of the enrichment effects were present throughout the experimental period, such as higher chl a content (Fig. 1a,b).

Living (fluorescing) cells were allocated to 47 taxonomical units on the level of species or genera and size classes. The biovolume was dominated by diatoms, although cyanobacteria (mainly chroococcales) and flagellates (mainly cryptophytes) were also present. Initially, 2 Navicula species (20 to $35 \mu \mathrm{m}$ long) were most common, accounting for 25 to $55 \%$ of the biovolume, with no significant effect of either nutrients or CPT (Fig. 2, Day 1). The diversity (note that $H^{\prime}$ was calculated from relative cell numbers, not relative cell volume) on Day 1 varied between 2.5 and 2.6, with no difference between any of the treatments (Fig. 1e,f).

After 3 wk (Day 24), large (>100 $\mu \mathrm{m}$ ) sigmoid diatoms belonging to the genera Pleurosigma and Gyrosigma 

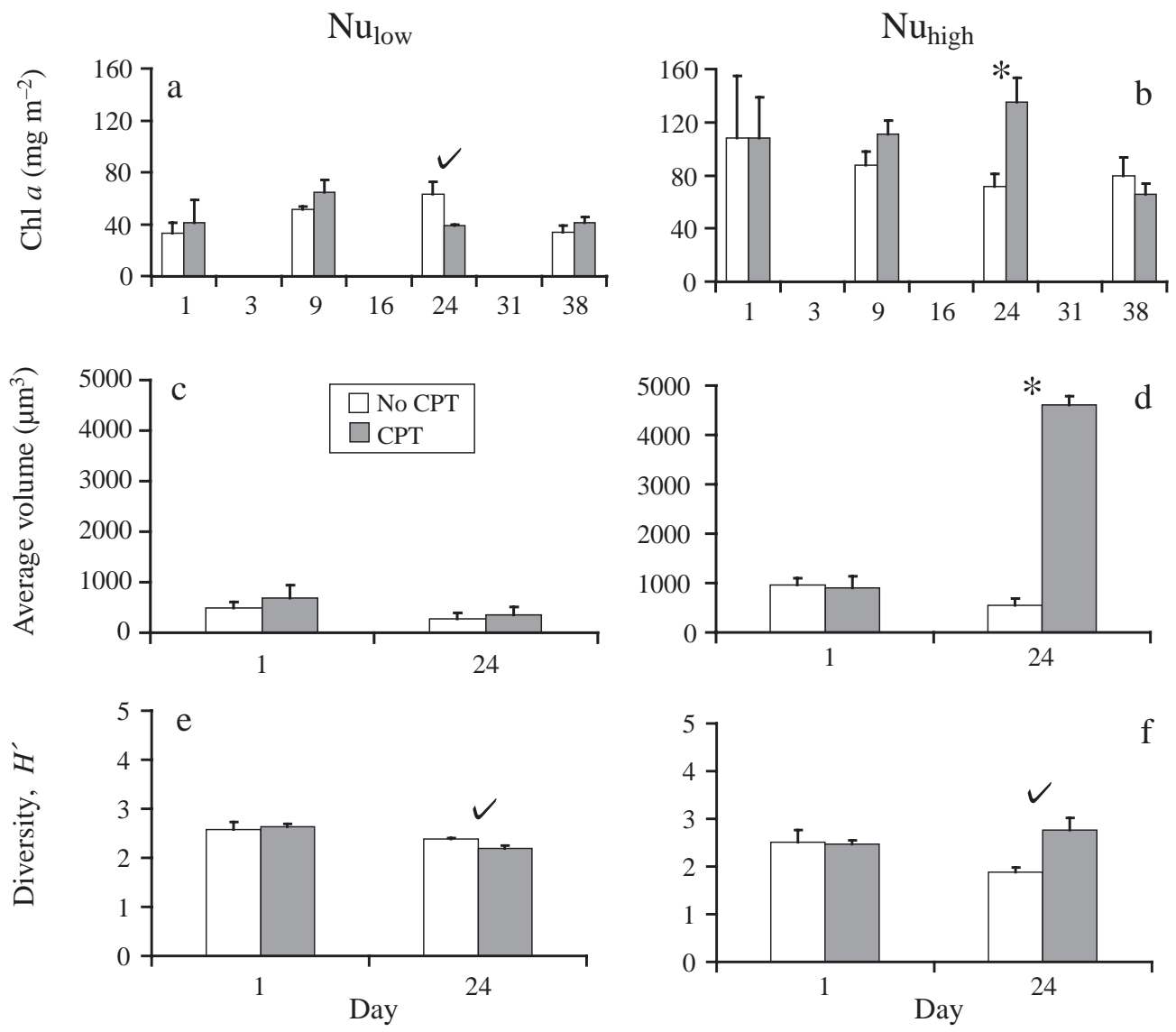

Fig. 1. Chlorophyll a content of the $(\mathrm{a}, \mathrm{b})$ sediment, $(\mathrm{c}, \mathrm{d})$ average algal cell volume and $(\mathrm{e}, \mathrm{f})$ algal diversity (Shannon-Weaver $\left.H^{\prime}\right)$ based on relative cell numbers in the $\mathrm{Nu}_{\text {low }}$ and $\mathrm{Nu}_{\text {high }}$ (low- and high-nutrient level, respectively) systems without and with addition of copper pyrithione $(\mathrm{CPT})$. Bars show means $+\mathrm{SE}, \mathrm{n}=3$. Significant CPT effects (SNK or 1 -way ANOVA) at $\mathrm{p}<0.05(*)$ and $\mathrm{p}<0.1(\mathcal{})$ are indicated

dominated the algal biovolume in the $\mathrm{Nu}_{\text {high }}$ systems (Fig. 2). The highest dominance in biovolume of a single species was found in the $\mathrm{Nu}_{\text {high }} \mathrm{CPT}$ treatment, where $P$. formosum ( $300 \mu \mathrm{m}$ long) accounted for 80 to $84 \%$ of the biovolume. This response was also reflected in a significantly $(\mathrm{p}<0.05)$ increased average cell volume (Fig. 1d). On Day 24, the proportion of cyanobacteria was lower in both CPT treatments $(0.1$ to $2.5 \%$ ) when compared with the 2 treatments without CPT (15 to $25 \%$; Fig. 2). CPT had also affected algal diversity by Day 24 , when the diversity was lower in the $\mathrm{Nu}_{\text {low }}$ system $(\mathrm{p}<0.1)$, while in the $\mathrm{Nu}_{\text {high }} \mathrm{CPT}$ treatment diversity was higher $(\mathrm{p}<0.1 ;$ Fig. $1 \mathrm{e}, \mathrm{f})$. The chl a content of the sediment had also increased in the $\mathrm{Nu}_{\text {high }}$ CPT treatment by Day 24 ( $\mathrm{p}<0.05$; Fig. $\left.1 \mathrm{~b}\right)$. The chl a:phaeopigment ratio was significantly $(\mathrm{p}<0.05)$ higher for Days 1 and 9 (by 40 and $65 \%$, respectively) in the $\mathrm{Nu}_{\text {high }} \mathrm{CPT}$ treatment.

The PCOs for the relative abundance of the 47 taxonomic units (PCOs based on Bray-Curtis dissimilarity; Fig. 3) show that already on Day 1, though not significantly, the groups had started to separate. On Day 24 there was a clear separation between $\mathrm{Nu}_{\text {low }}$ and $\mathrm{Nu}_{\text {low }} \mathrm{CPT}$ as well as between $\mathrm{Nu}_{\text {high }}$ and $\mathrm{Nu}_{\text {high }} \mathrm{CPT}$, and where the $\mathrm{Nu}_{\text {low }} \mathrm{CPT}$ show an overlap with $\mathrm{Nu}_{\text {high }}$.

\section{Bacteria}

Bacterial abundance was higher $(p<0.05)$ in the $\mathrm{Nu}_{\text {high }}$ than in the $\mathrm{Nu}_{\text {low }}$ treatment (Fig. $4 \mathrm{a}, \mathrm{b}$, Day 1 ), and nutrient enrichment also affected bacterial diversity, as more bands were visible on the DGGE gel on Day 1 in $\mathrm{Nu}_{\text {high }}$ compared to in $\mathrm{Nu}_{\text {low }}$ (gels not shown).

In the $\mathrm{Nu}_{\text {low }} \mathrm{CPT}$ treatment, bacterial abundance had increased by Day 9 ( $p<0.05$; Fig. 4 a), but the DGGE gel showed no change in bacterial diversity when compared to $\mathrm{Nu}_{\text {low }}$. There was also an increase in the bacterial abundance in the $\mathrm{Nu}_{\text {high }} \mathrm{CPT}$ treatment with a main factor effect ( $p=0.10$; Fig. $4 b$ ). 
Day 1

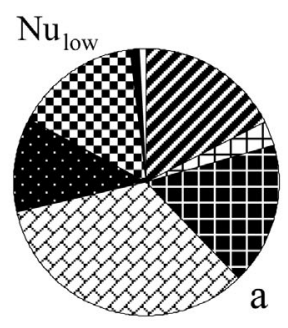

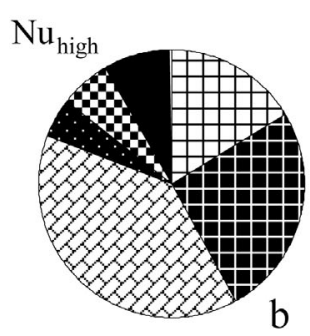

Day 24
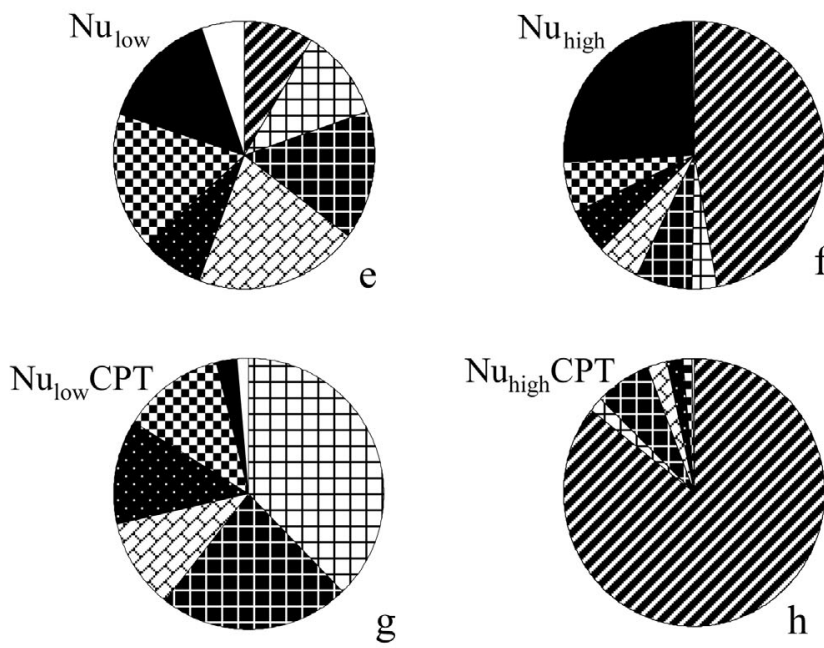

Other diatoms $0.5-2$ 8 Diatoms $<0.5$
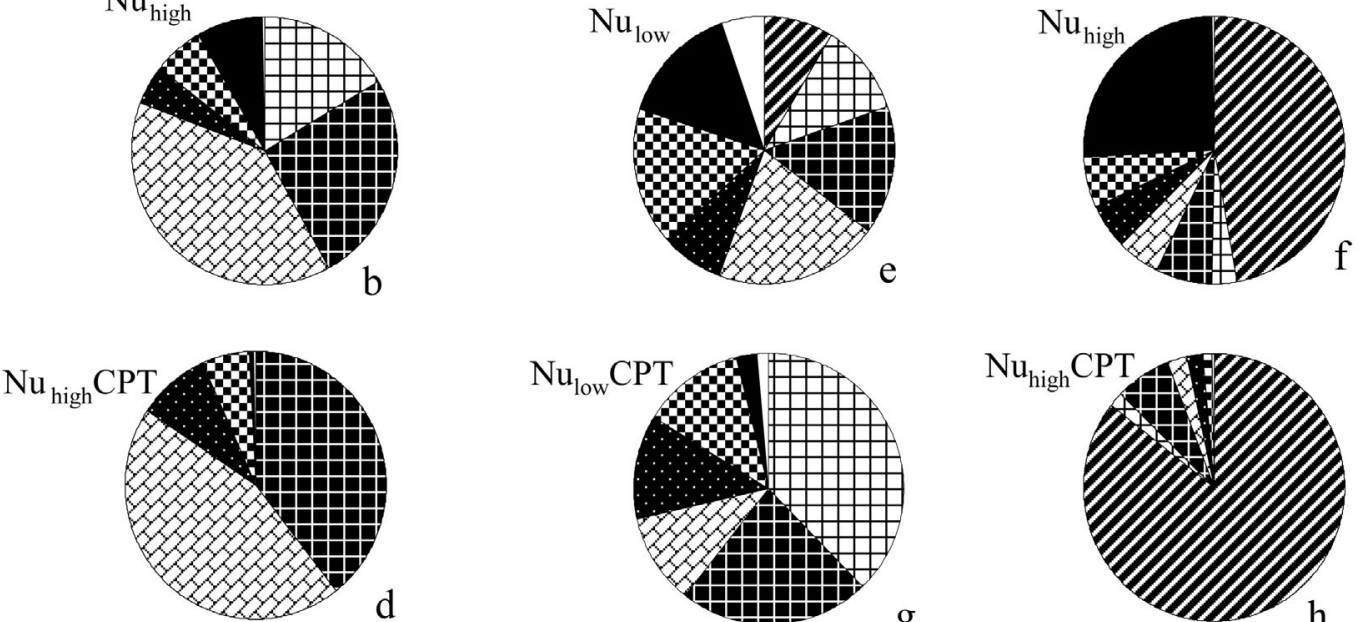

\#iatoms $>2$

$\bigotimes$ Naviculoids $0.5-2$

\section{\# Diatoms $>5$}

Fig. 2. Composition of microphytobenthos on $(\mathrm{a}-\mathrm{d})$ Days 1 and $(\mathrm{e}-\mathrm{h}) 24$ shown as proportions of total algal biovolume. Identified taxonomical units have been allocated to 8 major groups. Shown are the mean proportions. Size groups of diatoms are given in numbers $\times 10^{3} \mu^{3}$. For treatments see Fig. 1

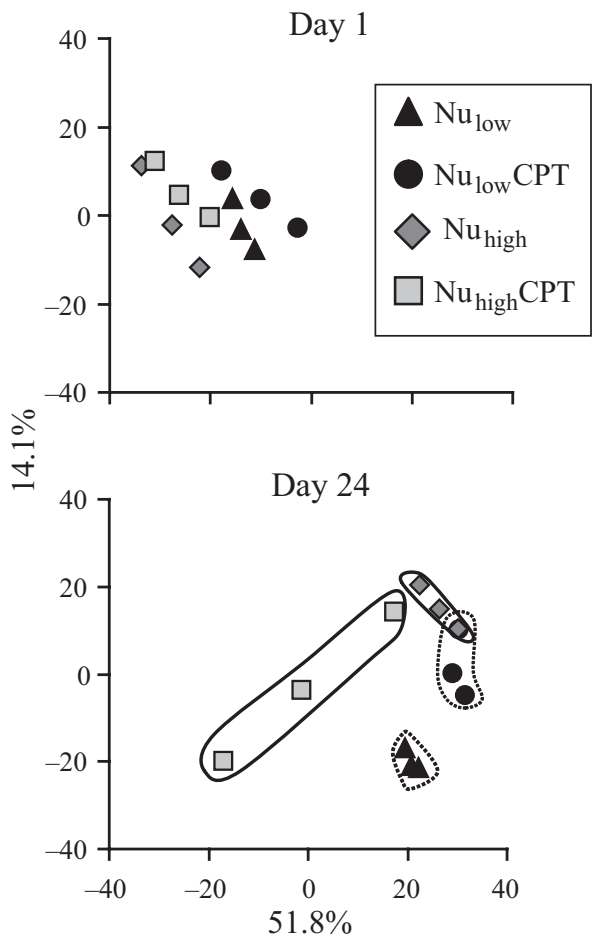

Fig. 3. Plots of principal coordinates (PCO) based on the data matrix of algal composition in the treatments. When sample groups differ significantly from each other in the PERMANOVA within a nutrient regime, they are encircled: lownutrient samples with dashed lines and high-nutrient samples with solid lines. Percentage values on each axis show the explained variance. For treatments, see Fig. 1

\section{Meiofauna}

Meiofauna consisted mainly of nematodes and harpacticoid copepods. Nutrient enrichment initially decreased meiofaunal density $(p<0.1)$ and increased the proportion of nematodes (Fig. $4 \mathrm{e}-\mathrm{h}$, Day 1).

CPT only affected the density of meiofauna on Day 24 , when the density was higher in $\mathrm{Nu}_{\text {high }} \mathrm{CPT}$ than in the $\mathrm{Nu}_{\text {high }}$ treatment ( $\mathrm{p}<0.05$; Fig. 4f,h).

\section{Macrofauna}

Infauna consisted mainly of the polychaetes Nereis sp., Arenicola marina and Pectinaria sp.; the bivalves Cerastoderma edule, Mya arenaria, Macoma baltica and Phaxas pellucidus; and the amphipod Corophium volutator. The total density of macrofauna was in the range of 200 to 400 ind. $\mathrm{m}^{-2}$. No pattern specific for any of the treatments was observed, and the densities were overall low when compared with our previous studies using the same type of sediment.

\section{Integrated community structure}

The integrated structure (including the variables chl $a$, meiofauna, bacterial abundance and sediment 

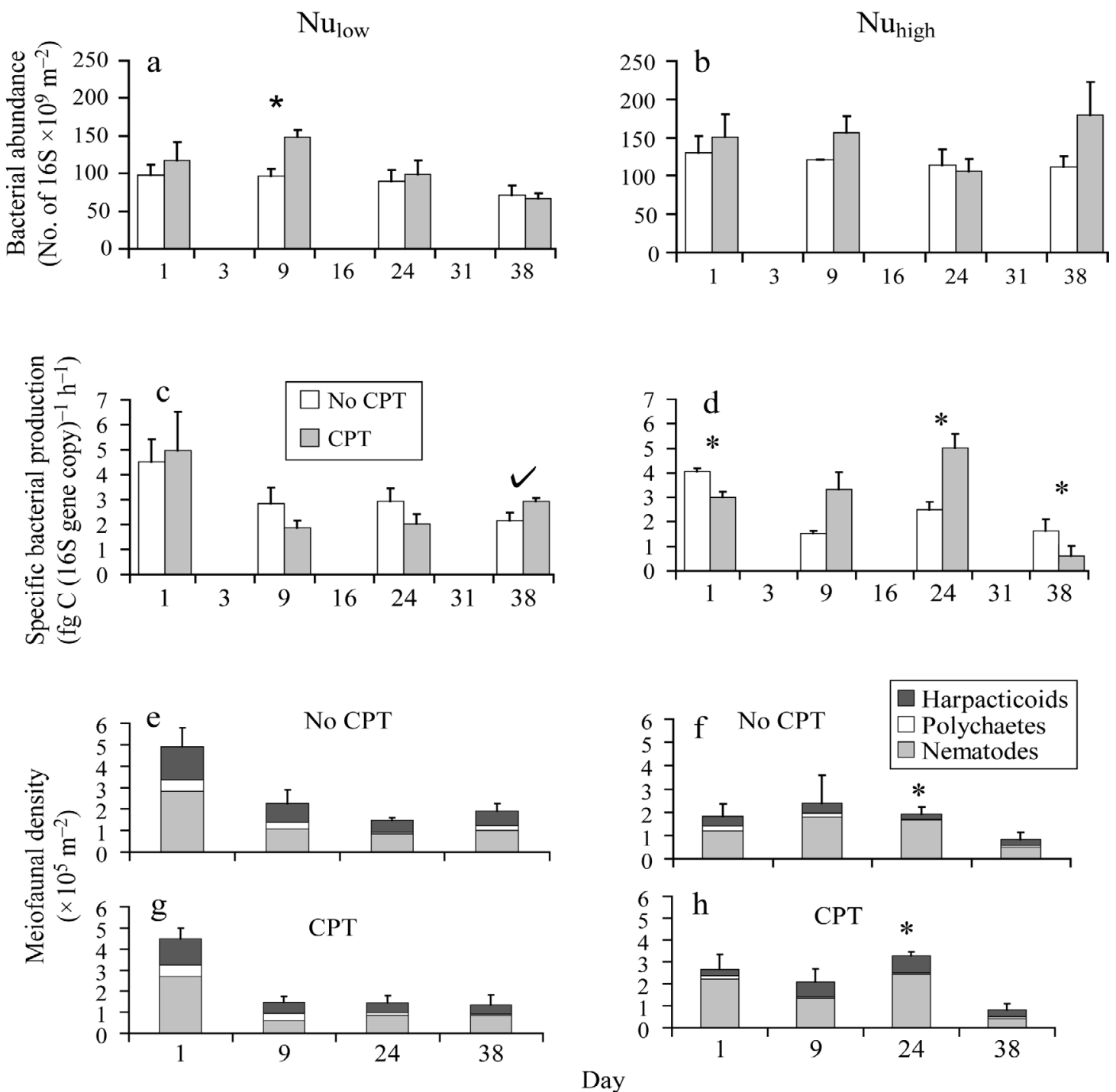

Fig. 4. (a,b) Bacterial abundance as number of $16 \mathrm{~S}$ gene copies in the sediment, (c,d) specific bacterial production (fg carbon per 16S gene copy), $(\mathrm{e}-\mathrm{h})$ meiofaunal density $\left(\times 10^{5}\right)$ and major composition. Shown are means $+\mathrm{SE}, \mathrm{n}=3$. Significant CPT effects (SNK or 1 -way ANOVA) at $\mathrm{p}<0.05(*)$ and $\mathrm{p}<0.1(\mathcal{})$ are indicated. For treatments, see Fig. 1

content of organic carbon and organic nitrogen) showed a separation based on the nutrient level $\left(\mathrm{Nu}_{\text {low }}\right.$ vs. $\left.\mathrm{Nu}_{\text {high }}\right)$, more or less throughout the experimental period without any signs of convergence, as analysed by PERMANOVA and visualised in the plots of PCOs (Fig. 5). The structure was also clearly separated between $\mathrm{Nu}_{\text {low }}$ and $\mathrm{Nu}_{\text {low }} \mathrm{CPT}$ on Days 9 and 24 ( $\mathrm{p}<0.05)$, while a significant separation was absent within the $\mathrm{Nu}_{\text {high }}$ system. A higher and lasting dispersion was caused by the initial nutrient addition ( $p<0.1$ ), and, by the end of the experiment, it showed that CPT had decreased dispersion in the $\mathrm{Nu}_{\text {low }}$ system, while the opposite was seen in the $\mathrm{Nu}_{\text {high }}$ system (both $\mathrm{p}<0.1$ ), as analysed by PERMDISP.

\section{Effects of nutrients and CPT on community function}

\section{Initial effects}

The 2 wk nutrient enrichment gave an increase in total algal and bacterial abundance that resulted in an overall higher community respiration $(\mathrm{CR}$, dark oxygen uptake; $\mathrm{p}<0.05$; Fig. 6a,b, Day 1). The outflux of phosphate in $\mathrm{Nu}_{\text {high }}$, particularly during the night $(\mathrm{p}<0.05)$, indicated that the $\mathrm{Nu}_{\text {high }}$ system was less oxygenated than the $\mathrm{Nu}_{\text {low }}$ system (Fig. $6 \mathrm{i}, \mathrm{j}$ ), which was in accordance with the observed increase in denitrification in $\mathrm{Nu}_{\text {high }}(\mathrm{p}<0.05$; Fig. $6 \mathrm{~g}, \mathrm{~h}$ ) and lower density of meiofauna ( $\mathrm{p}<0.1$; Fig. $4 \mathrm{e}-\mathrm{h}$ ). Oxygen production in light (microphytobenthic net primary production, NPP) 


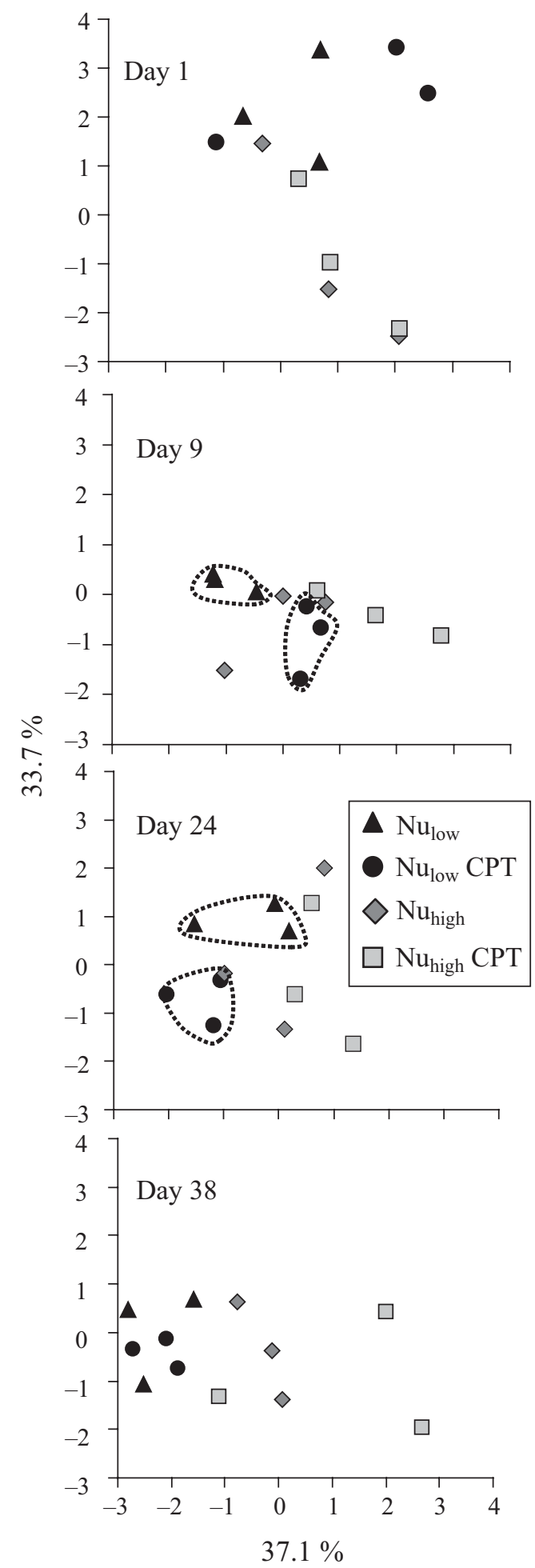

Fig. 5. Integrated community structure plotted as principal coordinates (PCO). Coordinates were calculated from a matrix including the variables $\mathrm{chl} a$, meiofaunal abundance, bacterial abundance and sediment content of organic carbon and nitrogen. Dashed lines encircle the low-nutrient groups when they differ significantly from each other in the PERMANOVA. Percentage values on each axis show the explained variance. For treatments, see Fig. 1 had increased by almost $100 \%$ in the $\mathrm{Nu}_{\text {high }}$ system by Day 1 ( $<<0.1$; Fig. 7a,b). Concomitantly, ammonium $(\mathrm{p}<0.1)$ and nitrate $(\mathrm{p}<0.05)$ uptake also increased in the light (Fig. $7 \mathrm{c}-\mathrm{f}$ ).

In the $\mathrm{Nu}_{\text {low }}$ system, the initial effects of CPT were primarily seen as a higher CR $(p<0.05)$ on Day 1 (Fig. 6a). A higher denitrification was also observed $(\mathrm{p}<0.05)$ on Day 1 (Fig. 6g).

In contrast to the $\mathrm{Nu}_{\text {low }}$ system, the initial effects of CPT addition in the $\mathrm{Nu}_{\text {high }}$ system led to lower $\mathrm{CR}(\mathrm{p}<$ 0.1 ; Fig. $6 b)$, large outflux of ammonium $(p=0.12)$ and lower denitrification ( $p<0.05$; Fig. $6 \mathrm{~h})$, all in the dark. Furthermore, a lower specific bacterial production was observed ( $\mathrm{p}<0.05$ ) on Day 1 in $\mathrm{Nu}_{\text {high }} \mathrm{CPT}$ (Fig. $\left.4 \mathrm{~d}\right)$.

\section{Later effects}

After Day 1, the effects of CPT on oxygen and nutrient fluxes were more often observed in the dark in the $\mathrm{Nu}_{\text {low }}$ system, where 7 incidences of significance were seen versus only 2 in the light $(p<0.1$; Table 2$)$. The exposure to $\mathrm{CPT}$ in $\mathrm{Nu}_{\text {low }}$ led to an increase in NPP ( $<<0.05$; Fig. 7a, Day 24), as well as nitrate uptake in the light ( $\mathrm{p}<0.1$; Fig. 7e, Day 24). In the dark, effects on nitrate flux (Fig. 6e, Days 9 and 38), silicate flux (Fig. 6k, Days 3 to 16) and oxygen consumption (Fig. 6a, Days 1 to 9) were evident. The specific bacterial production increased on Day $38(\mathrm{p}<0.1$; Fig. $4 \mathrm{c})$.

In the $\mathrm{Nu}_{\text {high }}$ system, CPT effects $(\mathrm{p}<0.1)$ on oxygen and nutrient fluxes were seen on 10 occasions in the light versus 9 in the dark (Table 2), and mostly as larger fluxes. The effects from the CPT addition in the $\mathrm{Nu}_{\text {high }}$ system were mainly seen as increased oxygen production $(\mathrm{p}<0.05$; Fig. $7 \mathrm{~b})$ in the middle of the experiment (Days 9 to 24), which coincided with increased silicate and ammonium uptake, both in the dark and the light (Figs. 61 \& 7j). The phosphate fluxes were also affected by CPT in both the dark and the light, resulting in a larger release of phosphate from the sediment on Day 9, but a lower release on Days 3 and 31 (Figs. 6j \& 7h) in $\mathrm{Nu}_{\text {high }} \mathrm{CPT}$ compared to in $\mathrm{Nu}_{\text {high }}$. In the mid-period of the experiment, the specific bacterial production increased (Fig. 4d). There was a main-factor effect of CPT on denitrification, with lower rates after CPT additions ( $p<0.05$; Fig. 6h).

\section{Integrated community function}

The integrated community function, including fluxes of oxygen and nutrients, depicted in the PCO plots (Fig. 8), showed that the $\mathrm{Nu}_{\text {low }}$ and $\mathrm{Nu}_{\text {low }}$ CPT systems were significantly separated only on Day 24 , in both the dark and the light as analysed by PERMANOVA and 


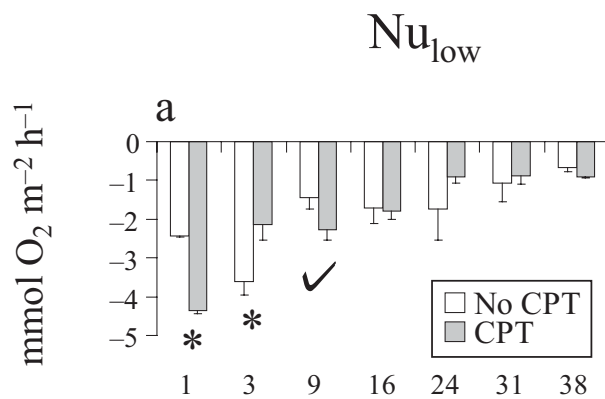

CR

$\mathrm{Nu}_{\text {high }}$

b

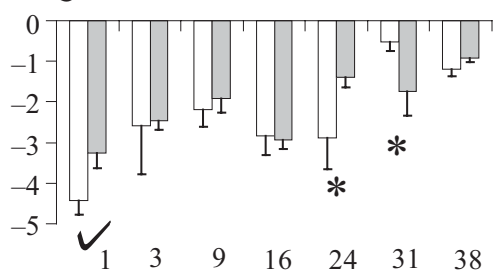

c

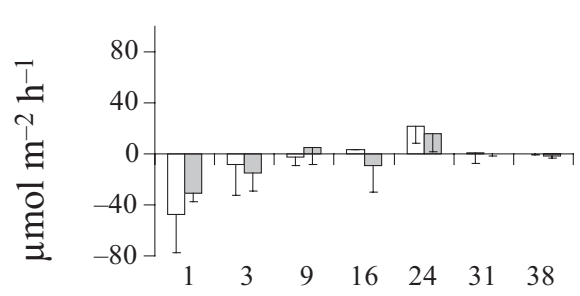

$\mathrm{NH}_{4}{ }^{+}$
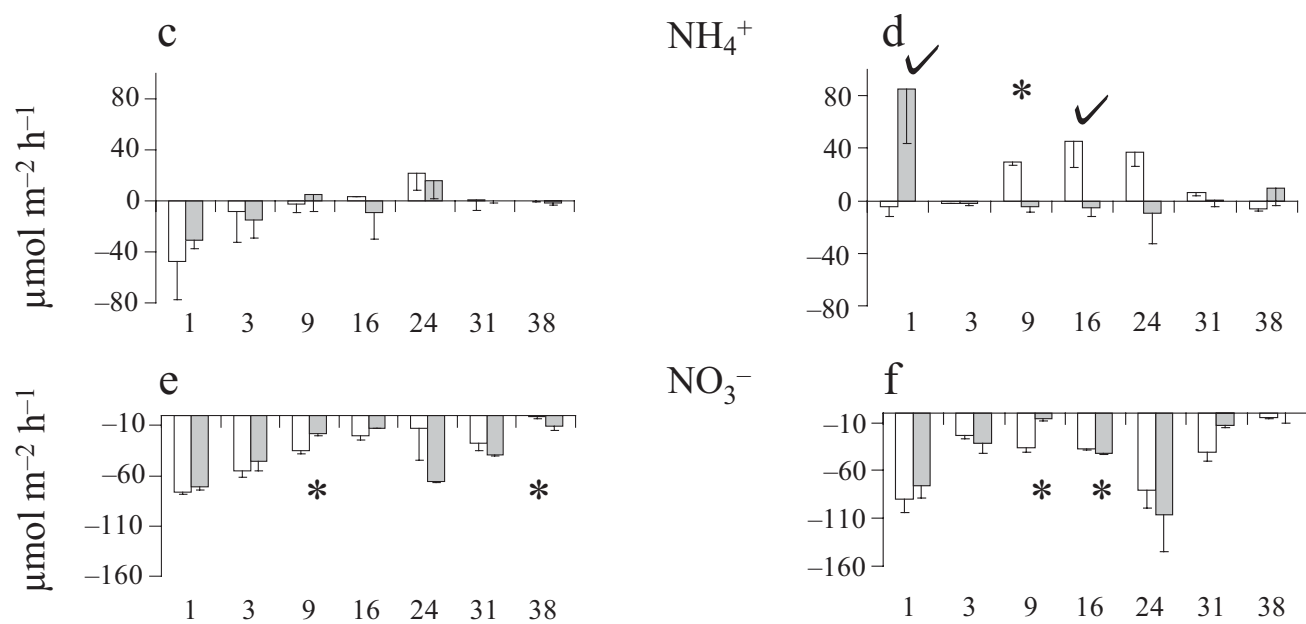

$\mathrm{NO}_{3}^{-}$
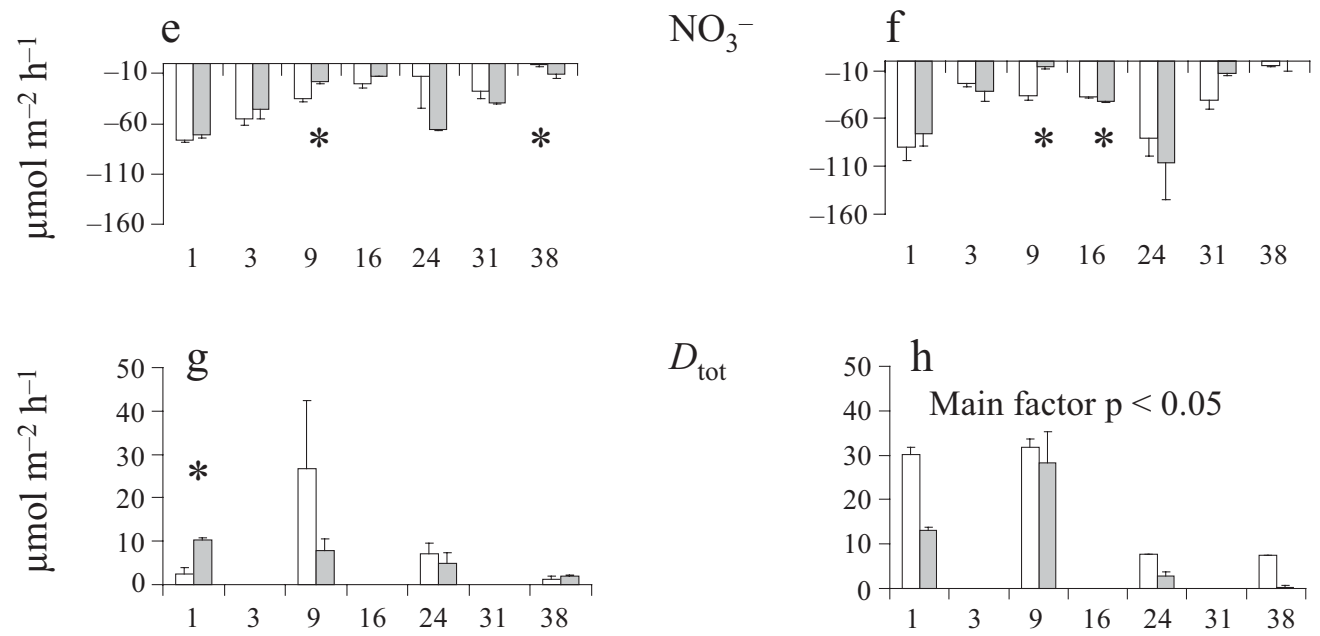

$D_{\text {tot }}$
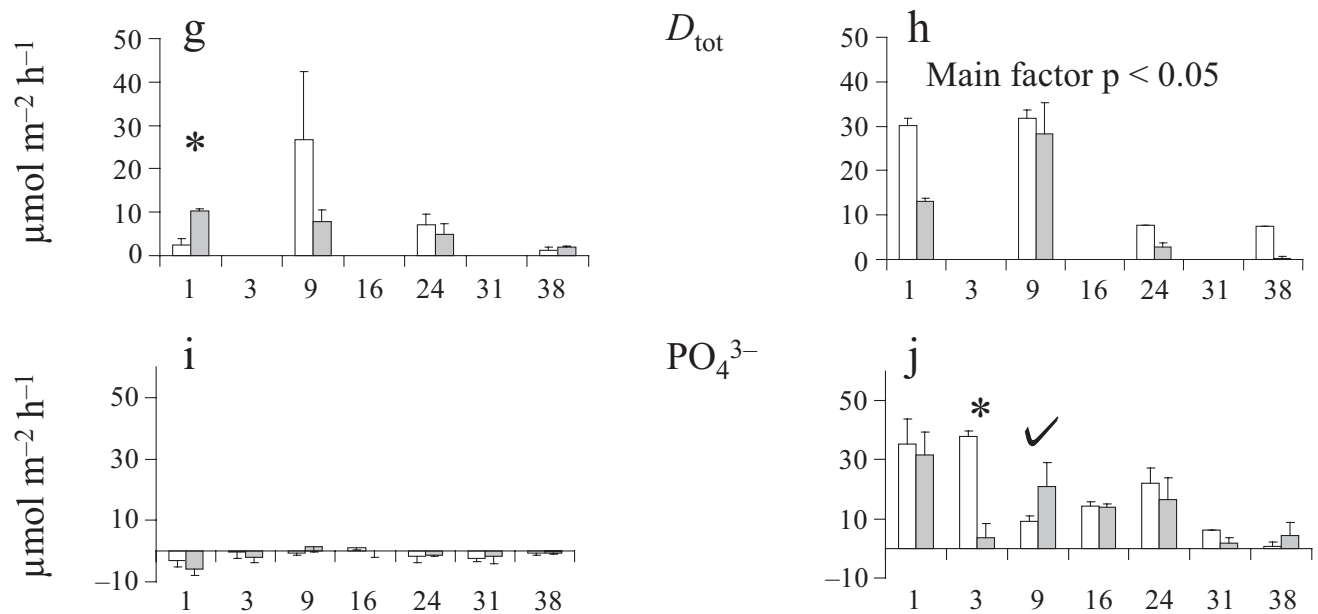

$\mathrm{PO}_{4}{ }^{3-}$
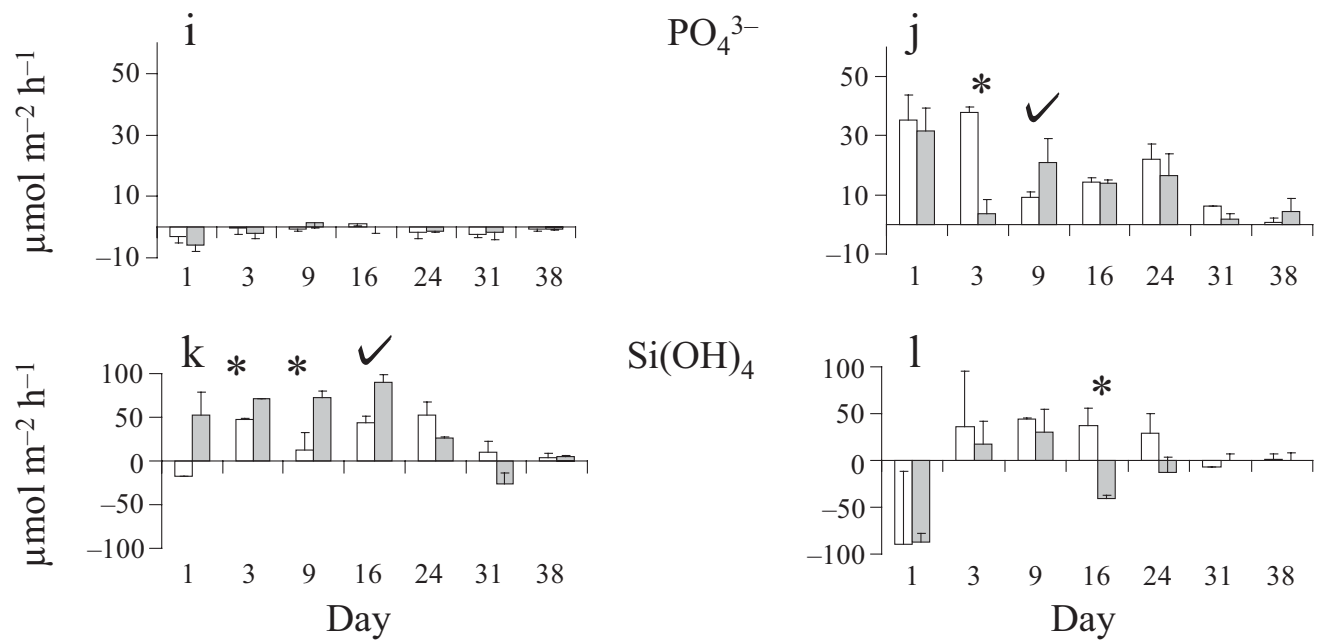

Fig. 6. Dark fluxes of oxygen and nutrients and denitrification. (a,b) Community respiration (CR, dark oxygen), (c,d) ammonium flux, $(\mathrm{e}, \mathrm{f})$ nitrate flux, $(\mathrm{g}, \mathrm{h})$ denitrification $\left(D_{\text {tot }}\right.$, only measured in the dark), $(\mathrm{i}, \mathrm{j})$ phosphate flux and $(\mathrm{k}, \mathrm{l})$ silicate flux. Shown are means $\pm \mathrm{SE}, \mathrm{n}=3$. Significant CPT effects (SNK or 1 -way ANOVA) at $\mathrm{p}<0.05(*)$ and $\mathrm{p}<0.1(\boldsymbol{})$ are indicated. Main factor effects are indicated by text in the graph. For treatments, see Fig. 1 

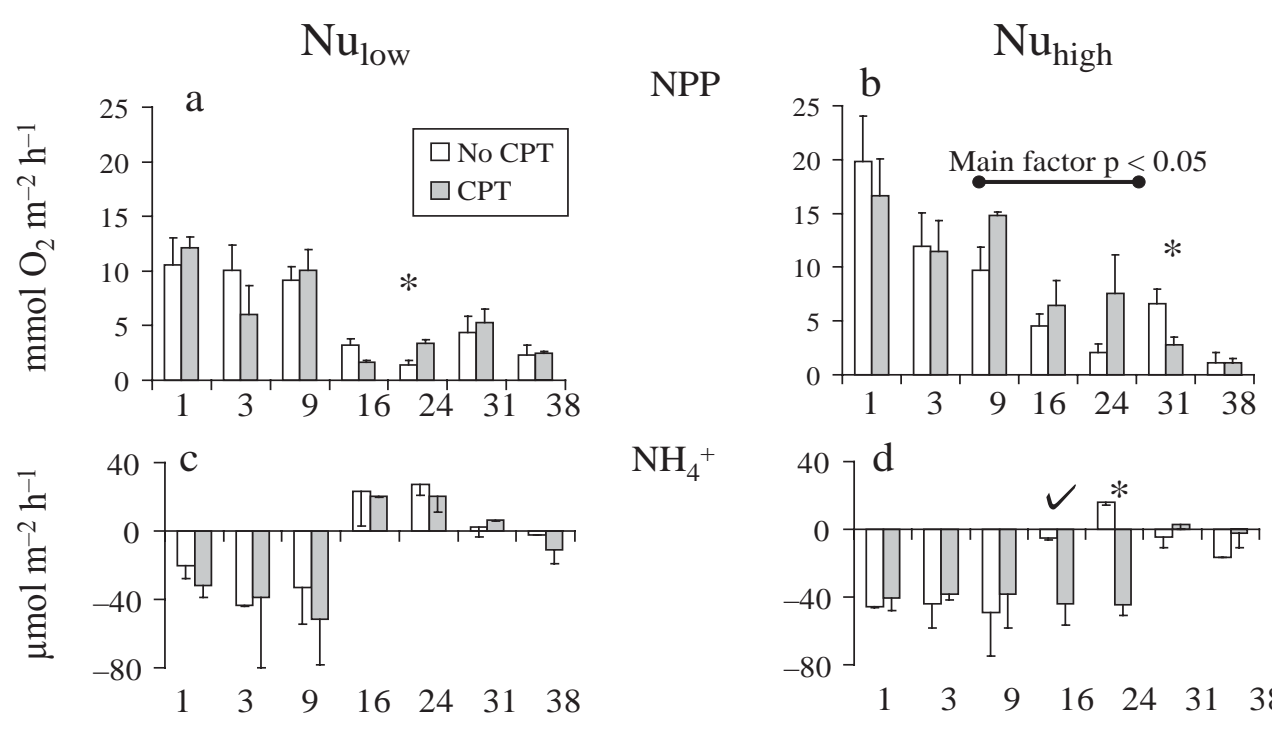

$\mathrm{NH}_{4}^{+}$
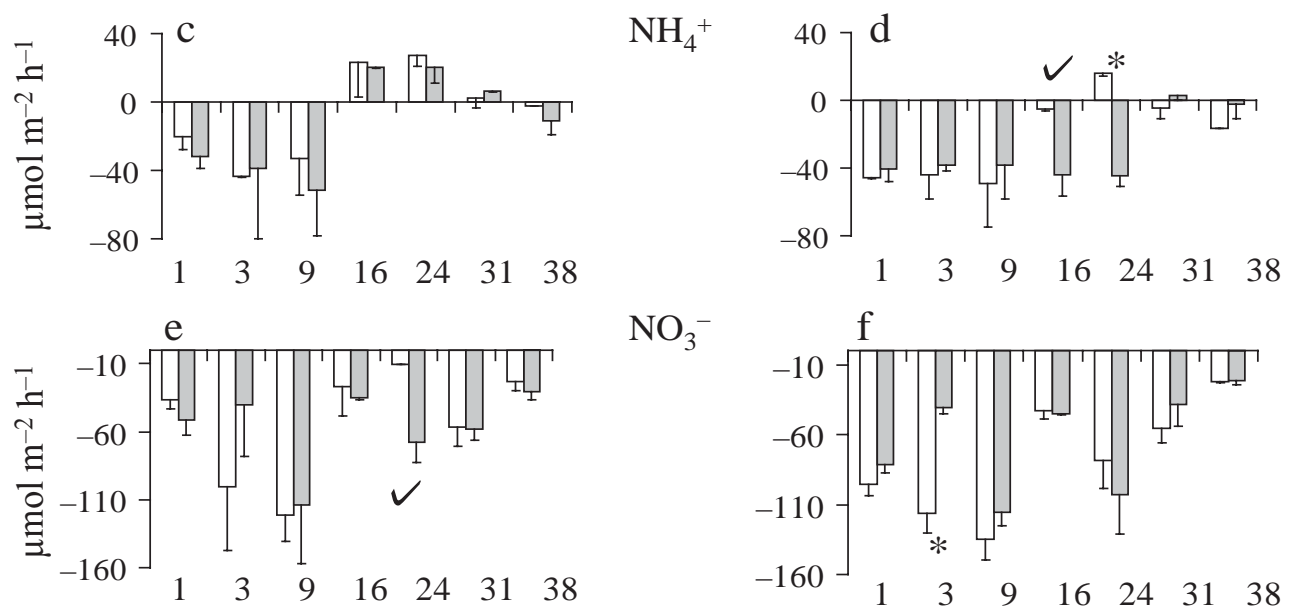

$\mathrm{NO}_{3}^{-}$
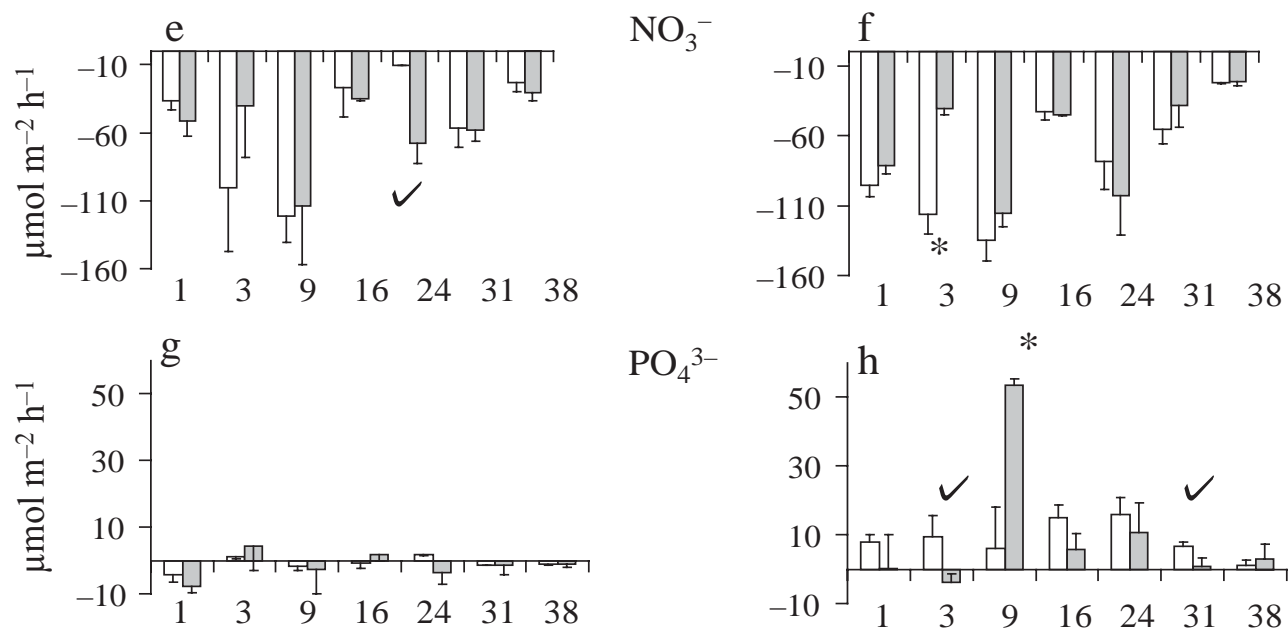

$\mathrm{PO}_{4}^{3-}$
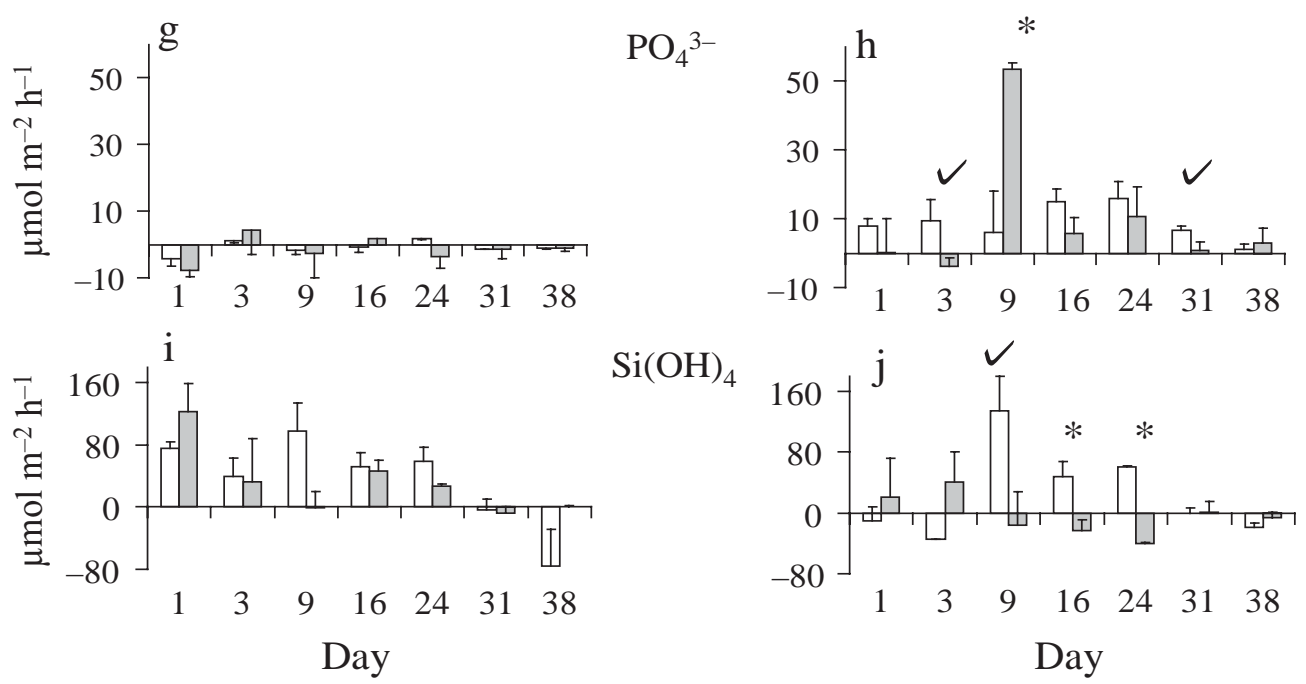

Fig. 7. Light fluxes of oxygen and nutrients. $(\mathrm{a}, \mathrm{b})$ Net primary production (NPP, oxygen flux; horizontal line indicates a main treatment effect of CPT on Days 9 to 24), (c,d) ammonium flux, $(\mathrm{e}, \mathrm{f})$ nitrate flux, $(\mathrm{g}, \mathrm{h})$ phosphate flux and $(\mathrm{i}, \mathrm{j})$ silicate flux. Shown are means $\pm \mathrm{SE}, \mathrm{n}=3$. Significant CPT effects (SNK or 1-way ANOVA) at $\mathrm{p}<0.05(*)$ and $\mathrm{p}<0.1(\mathcal{V})$ are indicated. For treatments, see Fig. 1

PERMDISP (Table 3). The CPT effects on the $\mathrm{Nu}_{\text {high }}$ systems were different temporal patterns in the light and the dark. In the dark, there was a separation between groups on Days 1 and 3, with a convergence of groups on Day 9 , followed once again by separation on Day 16, after which the groups re-converged and tightened up together until the end of the experiment. In the light, the groups in the $\mathrm{Nu}_{\text {high }}$ system were not separated on Day 1 , but showed a larger dispersion than in the $\mathrm{Nu}_{\text {low }}$ system. From Day 3 until Day 24, $\mathrm{Nu}_{\text {high }}$ and $\mathrm{Nu}_{\text {high }} \mathrm{CPT}$ treatments were clearly separated, followed by a reconvergence and a similar tightening of the groups as was seen in the dark. The convergence between the $\mathrm{Nu}_{\text {low }}$ and $\mathrm{Nu}_{\text {high }}$ systems from Day 31 also showed that the community functions of the $\mathrm{Nu}_{\text {high }}$ systems recovered from the effects of the initial nutrient addition. 


\section{DISCUSSION}

Few studies have focused on the effects of low-dose, short-term exposure to contaminants in multi-species systems or on a community level (Dahl \& Blanck 1996, Taub 1997, Blanck 2002). The CPT additions used in our experiment were at the nano-molar level per gram dry sediment, i.e. similar to the lowest effect concentrations found in short-term laboratory microcosm experiments in which CPT was added once to homogenised and sieved sediment (Petersen et al. 2004). Despite the high natural heterogeneity and variability of the natural sediment in our mesocosm experiment, effects of these low-dose CPT additions were measurable in both the high- and low-nutrient sediments.

\section{General patterns of response}

Our results show that nutrient status indeed affected the sensitivity of the shallow-water benthic community, as effects of CPT were more frequently observed in the $\mathrm{Nu}_{\text {high }}$ system. Main factor effects or interactions at the level $p<0.1$ were observed for 12 variables compared with only 5 variables in the $\mathrm{Nu}_{\text {low }}$ system (Table 2). This is similar, though not directly comparable, to the increased effect of trace metals when combined with nutrient enrichment, as described by Breitburg et al. (1999). This pattern may indicate a larger potential of response among organisms - and communities - under higher nutrient regimes, as has also been found by Cooke et al. (2006) when using UV as a combined stressor. Our results also suggest that the effects of the combination of CPT and nutrients cannot be predicted by simply adding the effects of nutrients and CPT, the effects of the combination thus being non-additive. For example, the diversity of microphytobenthos decreased when subjected to CPT only, while it increased with the combination of CPT and nutrient enrichment. This agrees with what Vinebrooke (2005) found in a meta-analysis of experiments combining 2 stressors.

There appeared to be more indirect than direct toxic effects from CPT, but had the impact of CPT also been measured directly after the first and second additions of CPT, the direct effects might have been more evident. The indirect effects were probably due to the intricate couplings between trophic levels, where small or undetectable effects on one level may have resulted in detectable impacts on another level. Bacteria appeared more sensitive to direct $\mathrm{CPT}$ exposure than did microphytobenthos. On Day 1, bacterialspecific production was more clearly affected than was primary production, in the $\mathrm{Nu}_{\text {high }}$ system, and the

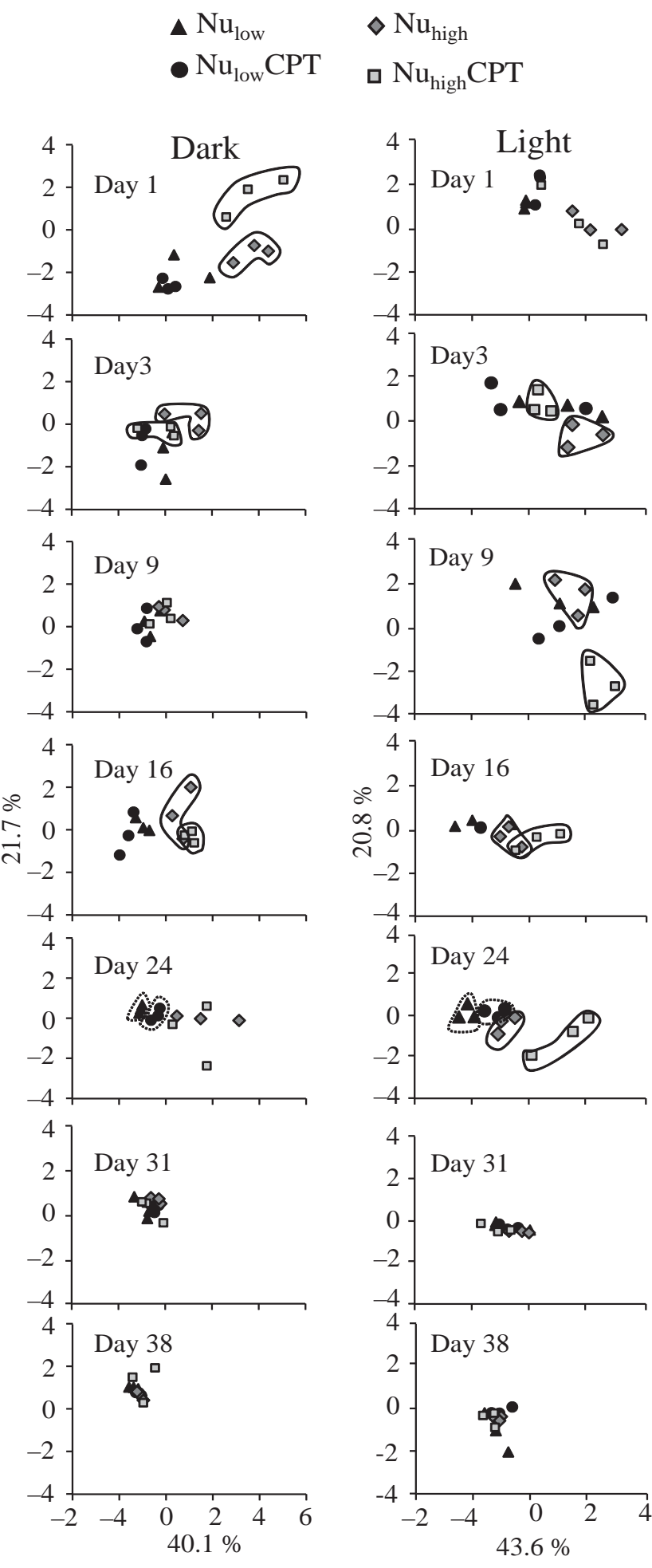

Fig. 8. Integrated community function plotted as principal coordinates (PCO). Coordinates were calculated from the matrices including the fluxes of oxygen and nutrients (ammonium, nitrate, phosphate and silicate) in the dark and light, respectively. Dashed lines encircle the low-nutrient groups and solid lines encircle the high-nutrient groups when they differ significantly in the PERMANOVA. Percentage values on each axis show the explained variance. For treatments, see Fig. 1 
Table 3. Results from a 2-way PERMANOVA and PERMDISP test, as well as pairwise a posteriori comparisons on the effects of CPT in the nutrient regimes for both functional and structural variables. Significant p-values $\leq 0.05$ are in bold and $p$-values $\leq 0.1$ in italics

\begin{tabular}{|c|c|c|c|c|}
\hline & \multicolumn{2}{|c|}{$-\mathrm{Nu}_{\text {low }} \longrightarrow$} & \multicolumn{2}{|c|}{$\longrightarrow \mathrm{Nu}_{\text {high }} \longrightarrow$} \\
\hline & PERMANOVA & PERMDISP & PERMANOVA & PERMDISP \\
\hline \multicolumn{5}{|c|}{ Functional } \\
\hline \multicolumn{5}{|c|}{ Light } \\
\hline Factor & $\mathrm{D} \times \mathrm{T}$ & $\mathrm{D} \times \mathrm{T}$ & $\mathrm{D} \times \mathrm{T}$ & $\mathrm{D} \times \mathrm{T}$ \\
\hline$F$ & 1.02 & 2.46 & 4.57 & 2.36 \\
\hline $\mathrm{p}$ & 0.46 & 0.047 & 0.0001 & 0.05 \\
\hline \multicolumn{5}{|l|}{ Dark } \\
\hline Factor & $\mathrm{D} \times \mathrm{T}$ & $\mathrm{D} \times \mathrm{T}$ & $\mathrm{D} \times \mathrm{T}$ & $\mathrm{D} \times \mathrm{T}$ \\
\hline$F$ & 2.08 & 1.39 & 3.63 & 4.55 \\
\hline $\mathrm{p}$ & 0.01 & 0.25 & 0.0002 & 0.0044 \\
\hline \multicolumn{5}{|c|}{ Structural } \\
\hline Factor & $\mathrm{D} \times \mathrm{T}$ & $\mathrm{D} \times \mathrm{T}$ & $\mathrm{D} \times \mathrm{T}$ & $\mathrm{D} \times \mathrm{T}$ \\
\hline$F$ & 1.68 & 4.83 & 0.83 & 4.59 \\
\hline $\mathrm{p}$ & 0.10 & 0.016 & 0.63 & 0.018 \\
\hline \multicolumn{5}{|c|}{ A posteriori pair-wise comparisons } \\
\hline & $\mathrm{p}$ (PERMANOVA) & $\mathrm{p}$ (PERMDISP) & $\mathrm{p}$ (PERMANOVA) & $\mathrm{p}$ (PERMDISP) \\
\hline \multicolumn{5}{|c|}{ Functional } \\
\hline \multicolumn{5}{|c|}{ Light } \\
\hline 1 & 0.25 & 0.09 & 0.67 & 0.49 \\
\hline 3 & 0.49 & 0.3 & 0.012 & 0.097 \\
\hline 9 & 0.4 & 0.29 & 0.031 & 0.099 \\
\hline 16 & 0.83 & 0.1 & 0.029 & 0.1 \\
\hline 24 & 0.034 & 0.099 & 0.019 & 0.3 \\
\hline 31 & 0.94 & 1.0 & 0.23 & 0.9 \\
\hline 38 & 0.41 & 0.4 & 0.31 & 0.1 \\
\hline \multicolumn{5}{|l|}{ Dark } \\
\hline 1 & 0.24 & 0.3 & 0.048 & 0.7 \\
\hline 3 & 0.35 & 0.4 & 0.023 & 0.2 \\
\hline 9 & 0.046 & 0.7 & 0.066 & 0.099 \\
\hline 16 & 0.15 & 0.4 & 0.028 & 0.1 \\
\hline 24 & 0.058 & 0.4 & 0.23 & 0.099 \\
\hline 31 & 0.41 & 0.1 & 0.066 & 0.3 \\
\hline 38 & 0.33 & 0.6 & 0.41 & 0.096 \\
\hline \multicolumn{5}{|c|}{ Structural } \\
\hline 1 & 0.75 & 0.29 & 0.88 & 0.50 \\
\hline 9 & 0.033 & 0.31 & 0.17 & 1.0 \\
\hline 24 & 0.038 & 0.30 & 0.35 & 0.50 \\
\hline 38 & 0.62 & 0.10 & 0.38 & 0.10 \\
\hline
\end{tabular}

of CPT in the $\mathrm{Nu}_{\text {high }}$ system was found for the nitrogen cycle, which is largely driven by bacterial processes, where ammonium fluxes and denitrification were both significantly affected.

The response of functional and structural variables to CPT additions in both the $\mathrm{Nu}_{\text {low }}$ and $\mathrm{Nu}_{\text {high }}$ systems resulted in temporal patterns different from those observed in the 2 systems without CPT throughout the experiment. Also, the temporal pattern of the response often appeared to be opposite for the $\mathrm{Nu}_{\text {low }}$ and $\mathrm{Nu}_{\text {high }}$ systems. The integrated community function showed a significant initial effect of CPT only in the $\mathrm{Nu}_{\text {high }}$ system and only in the dark (Fig. 8, Day 1). This further corroborates that the heterotrophic component was more affected by CPT on Day 1 compared to the autotrophic component.

\section{Structure}

In studying intact sediments, we could expect a complex combination of direct (toxic) and indirect (food-web mediated) effects to occur during the experiment. Direct effects may be difficult to discern, as they can be masked by indirect effects (e.g. Fleeger et al. 2003). In fact, indirect food-web effects may become more significant than direct toxic effects of a contaminant, particularly at low toxicant concentrations (Preston 2002, Fleeger et al. 2003), as in our study.

decreased proportion of cyanobacteria among primary producers also indicated that prokaryotes were more affected by CPT than eukaryotes. However, lack of evidence for direct effects on microphytobenthos could also be due to the fact that effects were first measured $4 \mathrm{~d}$ after the first CPT addition. The photoautotrophic community generally appeared to possess a higher functional redundancy than did the groups of heterotrophic organisms, as also indicated by the more pronounced effects on dark fluxes than on light fluxes. This could, however, have been caused by both direct $\mathrm{CPT}$ effects on bacteria and indirect effects from additional labile organic matter. The most evident effect
Parts of the meiofauna community, i.e. harpacticoid copepods and polychaete larvae, appeared to be negatively affected by the combination of CPT and nutrients. This was reflected in the $\mathrm{Nu}_{\text {high }} \mathrm{CPT}$ system as an indirect top-down effect (decreased grazing pressure) on the microalgae, which increased in both biomass and diversity as the dominance of nematodes increased.

CPT did not seem to have any significant direct toxic effects on the diversity of benthic microalgae. Smallsized diatoms $(<10 \mu \mathrm{m})$ could not be identified to species level, and, therefore, changes within this size group may have remained undetected. On the other hand, this size group made up only $<2 \%$ of the algal 
bio-volume. It is thought to be quite clear that the algal composition in the treatments had started to separate already on Day 1. Changes in the proportion of diatom size groups were seen, with a general increase towards larger sized diatoms in the CPT treatment. This size change might also have lowered the probability for the algae to be grazed and thereby changed the further transmission through the food web mediated by the meiofauna (Vinebrooke et al. 2004). The fact that the proportion of cyanobacteria initially decreased suggests that prokaryotes were more sensitive to CPT than were the diatoms. The combined effects of nutrients and CPT later on in the experiment were evident as strongly stimulated growth of large sigmoid diatoms and also a higher diversity compared to $\mathrm{Nu}_{\text {high }}$, which showed a decrease in diversity. Note that the diversity index was based on the relative number of cells and not the algal cell bio-volume. A lower diversity of microphytobenthos with nutrient enrichment has also been reported in previous studies (Sundbäck \& Snoeijs 1991, Underwood et al. 1998, Agatz et al. 1999). The higher algal diversity on Day 24 in the $\mathrm{Nu}_{\text {high }} \mathrm{CPT}$ treatment coincided with increased chl a content of the sediment and increased net oxygen production (Days 9 to 24), and can be interpreted as an indirect response caused by a top-down effect mediated through decreased grazing by meiofauna. A tight coupling has been found to exist between microphytobenthos and meiofauna (Pinckney et al. 2003).

We suggest that in the $\mathrm{Nu}_{\text {low }} \mathrm{CPT}$ system, only a small initial elimination of sensitive algae occurred due to lower total algal biomass. In the $\mathrm{Nu}_{\text {high }} \mathrm{CPT}$ system, the initial elimination was proportionally the same as that in the $\mathrm{Nu}_{\text {low }} \mathrm{CPT}$ system, but the larger supply of nutrients and changed grazing pressure allowed the growth of opportunistic resistant algae. The increased microphytobenthic diversity in $\mathrm{Nu}_{\text {high }} \mathrm{CPT}$ is likely to be connected to the change in composition of meiofauna in the same treatment, in combination with the growth of opportunistic algal species. While species grazed by nematodes could be expected to have been proportionally more grazed in this treatment, species mainly grazed by polychaete larvae and harpacticoid copepods had an advantage through less competition for resources and lowered risk of grazing. Both harpacticoid copepods and nematodes can be highly selective in their feeding preferences (Montagna et al. 1995, Azovsky et al. 2005), and the level of grazing can also be influenced without measurable changes in meiofaunal density, since toxic substances can have sub-lethal effects on the activity of the fauna (Carman et al. 1997). In our experiment this is also suggested by the simultaneous increase in microphytobenthic biomass, i.e. larger diatom species that were less grazed by nematodes and grazed earlier by harpacticoid cope- pods increased and became dominant in biomass, though not in numbers. Concentration of chl a degradation products are often used as indicators of grazing pressure, although recently criticised by Ford \& Honeywill (2002). The higher ratio of chl a:phaeopigments during the first week (Days 1 and 9) in the $\mathrm{Nu}_{\text {high }} \mathrm{CPT}$ treatment could indicate that the grazing pressure was lower.

Macrofaunal densities were low in the sediment we used, especially those of species known to graze on microalgae, such as the polychaete Nereis diversicolor, the amphipod Corophium volutator (Smith et al. 1996) and the bivalve Macoma baltica (Webb 1993). The gastropod Hydrobia ulvae, which is a major grazer of microphytobenthos (Blanchard et al. 2000), was not present at all.

\section{Function}

We suggest that the direct toxic effects from the CPT addition in both systems, despite their different nutrient status, resulted in increased amounts of available labile organic matter from newly dead organisms. However, after this initial response, the 2 systems evolved differently, since the outcome of the indirect effects depended on the level of available organic material and regeneration of nutrients. All 4 systems were strongly autotrophic on a $24 \mathrm{~h}$ time scale throughout the experiment (Sundbäck et al. 2007). Below we present a partly hypothetical interpretation of the functional development of the systems.

In the $\mathrm{Nu}_{\text {low }}$ system, the development after CPT exposure resulted initially in increased community respiration, but no indication of increased specific bacterial production was found. Increased specific bacterial production does, however, not necessarily result in increased protein synthesis if the bacterial degradation is dissimilatory. It has also been shown that the oxygen consumption in heterotrophic organisms can increase as a stress response to toxicants (Valsecchi et al. 1955, Odum 1985). The increased bacterial aerobic degradation in the $\mathrm{Nu}_{\text {low }} \mathrm{CPT}$ system is also indicated by increased silicate flux from the sediment. The observed increase in denitrification on Day 1 in $\mathrm{Nu}_{\text {low }} \mathrm{CPT}$ could have been facilitated by the degradation of labile organic matter, leading to a less oxygenated environment at night, but also by increased substrate availability in the CPT-amended samples. No initial effects on the function of the algae were observed in $\mathrm{Nu}_{\text {low }} \mathrm{CPT}$, as indicated by unchanged oxygen production. However, we suggest that the algae were directly affected by CPT before Day 1, which is indicated by an increased silicate outflux in both the light and the dark and a tendency towards lower algal production on 
Day 1. The additional recycling of dead organic matter in $\mathrm{Nu}_{\text {low }} \mathrm{CPT}$ could thereby have hidden effects of CPT, since the algae in this treatment had a better supply of nutrients compared to $\mathrm{Nu}_{\text {low }}$.

In the $\mathrm{Nu}_{\text {high }}$ system, the initial effects of CPT addition on Day 1 showed a different response compared to $\mathrm{Nu}_{\text {low }} \mathrm{CPT}$, despite the assumed same toxic effects of $\mathrm{CPT}$ as in the $\mathrm{Nu}_{\text {low }}$ systems. The main initial effects in the $\mathrm{Nu}_{\text {high }} \mathrm{CPT}$ treatment were seen on the nitrogen cycle. There was an increased outflux of ammonium in the dark that resulted in a net outflux on a time scale of $24 \mathrm{~h}$ (Sundbäck et al. 2007). Increased bacterial ammonification of labile organic material and decreased algal uptake of ammonium could explain these initial responses of the nitrogen cycle. Furthermore, a decreased nitrification rate could also have caused increased ammonium flux from the sediment. Nitrification is a process with low functional redundancy (Wolters et al. 2000), which implies that the effects from CPT on nitrifying bacteria are easy to recognise. Direct effects from toxic compounds, e.g. TBT, ZPT and $\mathrm{CPT}$, on nitrification have been shown to occur, resulting in an uncoupling of ATP production, leading to a short-term stimulation of ammonium consumption (Dahllöf et al. 1999, Petersen et al. 2004). This shortterm stimulation of nitrification does not produce energy and will eventually result in a reduction of the nitrification, causing increased ammonium outflux, as seen on Day 1 in our experiment. Because nitrifiers also have a low growth rate (Glover 1985), the direct toxic effects from CPT on nitrifiers occurring initially would be traceable as decreased nitrification during the first days of our experiment.

A combined effect on the substrate producers for the denitrification, as well as on the denitrifying bacteria, caused the initial effects of CPT on denitrification observed in the $\mathrm{Nu}_{\text {high }}$ treatment. This led to a decrease in denitrification of approximately $55 \%$, which is comparable to results reported by Petersen et al. (2004). This decrease in denitrification in $\mathrm{Nu}_{\text {high }}$ was in contrast to the initial increase observed in the $\mathrm{Nu}_{\text {low }}$ treatment. We suggest that the effect of CPT on denitrification in $\mathrm{Nu}$ low $\mathrm{CPT}$ was the same as in $\mathrm{Nu}_{\text {high }} \mathrm{CPT}$, but since the denitrification in the $\mathrm{Nu}_{\text {low }}$ system was probably more substrate limited, as mentioned above, the CPT effect of increased labile organic material resulted in a seemingly higher denitrification in the $\mathrm{Nu}_{\text {low }} \mathrm{CPT}$. Since there probably was lower substrate limitation in the $\mathrm{Nu}_{\text {high }}$ system, the observed effects of CPT on the $\mathrm{Nu}_{\text {high }}$ system reflected the actual direct toxic effects on denitrifiers. The level of denitrification in $\mathrm{Nu}_{\text {low }} \mathrm{CPT}$ was also similar to the level of denitrification in $\mathrm{Nu}_{\text {high }} \mathrm{CPT}$, reaching a maximum rate of $10 \mu \mathrm{mol} \mathrm{N} \mathrm{m}^{-2} \mathrm{~h}^{-1}$.

Effects after Day 1 were more pronounced in the $\mathrm{Nu}_{\text {high }}$ system, where significant main effects or inter- actions $(p<0.05)$ were present for 8 variables and in a total of 22 incidences compared to only 3 variables and 8 incidences in the $\mathrm{Nu}_{\text {low }}$ system (Table 2).

The differences in indirect effects between the 2 enrichment regimes suggest that the interaction between nutrients and CPT could not be predicted by simple additive effects or by multiplying a factor related to the degree of enrichment. For example, the observed stimulation of specific bacterial production on Days 9 and 24 in $\mathrm{Nu}_{\text {high }} \mathrm{CPT}$ was different from the indirect effects seen in $\mathrm{Nu}_{\text {low }} \mathrm{CPT}$. During the same period (Days 9 to 24), the chl a concentration of the sediment and oxygen production in light, together with the uptake of ammonium and silicate, increased in the $\mathrm{Nu}_{\text {high }} \mathrm{CPT}$ system. This was more or less the opposite pattern compared to what was found in the $\mathrm{Nu}_{\text {low }} \mathrm{CPT}$ treatment. The increase of denitrification in $\mathrm{Nu}_{\text {low }} \mathrm{CPT}$ versus the decrease in $\mathrm{Nu}_{\text {high }} \mathrm{CPT}$ is another example of the opposite pattern of response. Furthermore, the $\mathrm{Nu}_{\text {low }} \mathrm{CPT}$ system bore the signature of eutrophication, in that bacterial abundance, structural dispersion and microphytobenthos diversity showed a similar response to that seen in the $\mathrm{Nu}_{\text {high }}$ system at the beginning of the experiment when compared to the $\mathrm{Nu}_{\text {low }}$ system.

Assuming that the results from our mesocosm experiment can be extrapolated to shallow-water bays with boating activities - and thereby potential CPT exposure-impacts in both mesotrophic and eutrophic bays could be expected, but with a different timing of effects or opposite patterns of response. Since the frequency of CPT impacts during the productive season ought to be higher than that in our experiment (4 nights of exposure), we can expect direct toxic impacts and indirect effects to occur simultaneously.

The CPT-induced internal release of labile organic material within the sediment system, together with indirect top-down effects through impacted fauna, can increase the biomass of opportunistic primary producers, thereby enforcing eutrophication-related symptoms. The lowered denitrification and community respiration seen in the high nutrient-level system would further increase the accumulation of nitrogen and organic material within the system, due to less decomposition and removal. Such reinforcement of eutrophication increases the risk of hypoxic events, especially when the pollution-depressed decomposition is recovering. Thus, the value of the bays as nurseries and part-time habitats for commercially important fish species and other fauna of importance to coastal fisheries would be decreased for a longer period, also when surrounding conditions have become sound.

The effects found in our experiment could potentially occur widely in coastal waters. In many cases the effects would probably be even greater, since these 
areas are exposed to a more or less continuous supply of anthropogenic nutrients. Also, our experimental systems represented shallow-water systems that were strongly autotrophic during the growth season. The fact that we found more CPT effects in heterotrophic components and functions suggests that CPT might have even greater effects on deeper lying, less autotrophic sediments.

Acknowledgements. Funding was received from the Swedish Research Council (VR), the Swedish Research Council for Environment, Agricultural Sciences and Special Planning (FORMAS), the Marine Research Centre of Göteborg University, the Nordic Council of Ministers, the Royal Society of Arts and Sciences in Göteborg, the Memorial Fund of Birgit and Birger Wåhlström, the Captain Stenholm Fund, the Letterstedtska Foundation and the Family Hede Nielsen Foundation. We thank M. Hjorth, R. Haller and D. W. Jensen (National Environmental Research Institute of Denmark); L. P. Nielsen and T. Lund Skovhus (University of Aarhus); and the crew of the RV 'Oscar von Sydow', Kristineberg Marine Research Station, for assistance. We also thank H. W. Paerl and 2 anonymous reviewers for their very valuable comments, which greatly improved the paper.

\section{LITERATURE CITED}

Agatz M, Asmus RM, Deventer B (1999) Structural changes in the benthic diatom community along a eutrophication gradient on a tidal flat. Helgol Mar Res 53:92-101

Anderson MJ (2001) A new method for non-parametric multivariate analysis of variance. Aust Ecol 26:32-46

Anderson MJ (2003) PCO: a FORTRAN computer program for principal coordinate analysis. Department of Statisics, University of Auckland

Anderson MJ (2004) PERMDISP: a FORTRAN computer program for permutational analysis of multivariate dispersion (for any two-factor ANOVA design) using permutation test. Department of Statistics, University of Auckland

Anderson MJ (2005) PERMANOVA: a FORTRAN computer program for permutational multivariate analysis of variance. Department of Statistics, University of Auckland

Azovsky AI, Saburova MA, Chertoprood ES, Polikarpov IG (2005) Selective feeding of littoral harpacticoids on diatom algae: Hungry gourmands? Mar Biol 148:327-337

Blanchard GF, Guarini JM, Provot L, Richard P, Sauriau PG (2000) Measurement of ingestion rate of Hydrobia ulvae (Pennant) on intertidal epipelic microalgae: the effect of mud snail density. J Exp Mar Biol Ecol 255:247

Blanck H (2002) A critical review of procedures and approaches used for assessing pollution-induced community tolerance (PICT) in biotic communities. Human Ecol Risk Assess 8:1003-1034

Breitburg DL, Sanders JG, Gilmour CC, Hatfield CA, Osman RW, Riedel GF, Seitzinger SB, Sellner KG (1999) Variability in responses to nutrients and trace elements, and transmission of stressor effects through an estuarine food web. Limnol Oceanogr 44:837-863

Brock TCM, Crum SJH, Deneer JW, Heimbach F, Roijackers RMM, Sinkeldam JA (2004) Comparing aquatic risk assessment methods for the photosynthesis-inhibiting herbicides metribuzin and metamitron. Environ Pollut 130:403-426
Carman KR, Fleeger JW, Pomarico SM (1997) Response of a benthic food web to hydrocarbon contamination. Limnol Oceanogr 42:561-571

Cloern JE (2001) Our evolving conceptual model of the coastal eutrophication problem. Mar Ecol Prog Ser 210: $223-253$

Cooke SL, Williamson CE, Saros JE (2006) How do temperature, dissolved organic matter and nutrients influence the response of Leptodiaptomus ashlandi to UV radiation in a subalpine lake? Freshw Biol 51:1827-1837

Dahl B, Blanck H (1996) Use of sand-living microalgal communities (epipsammon) in ecotoxicological testing. Mar Ecol Prog Ser 144:163-173

Dahllöf I, Hall P, Blanck H (1999) Short-term effects of tri-nbutyl-tin on marine sediment samples using nutrient fluxes as effect indicators. Environ Toxicol Chem 18:850

Dahllöf I, Baillie H, Kjelleberg S (2000) rpoB-Based microbial community analysis avoids limitations inherent in $16 \mathrm{~S}$ rRNA gene intraspecies heterogeneity. Appl Environ Microbiol 66:3376

Dalsgaard T, Nielsen LP, Brotas V, Viaroli P and 11 others (2000) Protocol handbook for NICE - nitrogen cycling in estuaries. Department of Lake and Estuarine Ecology, Ministry of Environment and Energy, National Environmental Research Institute, Silkeborg

Faimali M, Piazza V, Falugi C, Gallus L, Tagliafierro G (2003) Involvement of acetyl choline in settlement of Balanus amphitrite. Biofouling 19:213

Fleeger JW, Carman KR, Nisbet RM (2003) Indirect effects of contaminants in aquatic ecosystems. Sci Total Environ 317:207-233

Folt CL, Chen CY, Moore MV, Burnaford J (1999) Synergism and antagonism among multiple stressors. Limnol Oceanogr 44:864-877

Ford RB, Honeywill C (2002) Grazing on intertidal microphytobenthos by macrofauna: Is phaeophorbide $a$ a useful marker? Mar Ecol Prog Ser 229:33-42

Glover HE (1985) The relationship between inorganic nitrogen oxidation and organic carbon production in batch and chemostat cultures of marine nitrifying bacteria. Arch Microbiol 142:45

Grunnet KS, Dahllöf I (2005) Environmental fate of the antifouling compound zinc pyrithione in seawater. Environ Toxicol Chem 24:3001-3006

Haglund K (1997) The use of algae in aquatic toxicity assessment. Prog Phycol Res 12:181-212

Heugens EHW, Hendriks AJ, Dekker T, van Straalen NM, Admiraal W (2001) A review of the effects of multiple stressors on aquatic organisms and analysis of uncertainty factors for use in risk assessment. Crit Rev Toxicol 31: $247-284$

Hillebrand H, Kahlert M (2002) Effect of grazing and water column nutrient supply on biomass and nutrient content of sediment microalgae. Aquat Bot 72:143-159

Hjorth M, Dahllof I, Forbes VE (2006) Effects on the function of three trophic levels in marine plankton communities under stress from the antifouling compound zinc pyrithione. Aquat Toxicol 77:105-115

Kobayashi N, Okamura H (2002) Effects of new antifouling compounds on the development of sea urchin. Mar Pollut Bull 44:748-751

Koelmans AA, Van der Heijde A, Knijff LM, Aalderink RH (2001) Integrated modelling of eutrophication and organic contaminant fate and effects in aquatic ecosystems. A review. Water Res 35:3517-3536

Laursen AE, Seitzinger SP, Dekorsey R, Sanders JG, Breitburg DL, Osman RW (2002) Multiple stressors in an estu- 
arine system: effects of nutrients, trace elements, and trophic complexity on benthic photosynthesis and respiration. Estuaries 25:57-69

Lenihan HS, Peterson CH, Kim SL, Conlan KE, Fairey R, McDonald C, Grabowski JH, Oliver JS (2003) Variation in marine benthic community composition allows discrimination of multiple stressors. Mar Ecol Prog Ser 261:63-73

Lorenzen CJ (1967) Determination of chlorophyll and pheopigments: spectrophotometric equations. Limnol Oceanogr 12:343-346

Maraldo K, Dahllöf I (2004a) Indirect estimation of degradation time for zinc pyrithione and copper pyrithione in seawater. Mar Pollut Bull 48:894-901

Maraldo K, Dahllöf I (2004b) Seasonal variations in the effect of zinc pyrithione and copper pyrithione on pelagic phytoplankton communities. Aquat Toxicol 69:189-198

McArdle BH, Anderson MJ (2001) Fitting multivariate models to community data: a comment on distance based redundancy analysis. Ecology 82:290-297

Millward RN, Carman KR, Fleeger JW, Gambrell RP, Portier R (2004) Mixtures of metals and hydrocarbons elicit complex responses by a benthic invertebrate community. J Exp Mar Biol Ecol 310:115-130

Montagna PA, Blanchard GF, Dinet A (1995) Effect of production and biomass of intertidal microphytobenthos on meiofaunal grazing rates. J Exp Mar Biol Ecol 185:149-165

Nacci D, Jackim E, Walsh R (1986) Comparative-evaluation of three rapid marine toxicity tests - sea-urchin early embryo growth test, sea-urchin sperm cell toxicity test and microtox. Environ Toxicol Chem 5:521-525

Nielsen LP (1992) Denitrification in sediment determined from nitrogen isotope pairing. FEMS Microbiol Ecol 86:357-362

Nielsen SL, Banta GT, Pedersen MF (2004) Estuarine nutrient cycling: the influence of primary producers. The fate of nutrients and biomass. Aquat Ecol 2:247-250

Odum EP (1985) Trends expected in stressed ecosystems. BioScience 35:419-422

Okamura H, Watanabe T, Aoyama I, Hasobe M (2002) Toxicity evaluation of new antifouling compounds using suspension-cultured fish cells. Chemosphere 46:945-951

Petersen DG, Dahllöf I (2005a) Improvements for comparative analysis of changes in diversity of microbial communities using internal standards in PCR-DGGE. FEMS Microbiol Ecol 53:339-348

Petersen DG, Dahllöf I (2005b) Improvements for comparative analysis of changes in diversity of microbial communities using internal standards in PCR-DGGE. FEMS Microbiol Ecol 53:339-348

Petersen DG, Dahllöf I, Nielsen LP (2004) Effects of zinc pyrithione and copper pyrithione on microbial community function and structure in sediments. Environ Toxicol Chem 23:921-928

Pinckney JL, Carman KR, Lumsden SE, Hymel SN (2003) Microalgal-meiofaunal trophic relationships in muddy intertidal estuarine sediments. Aquat Microb Ecol 31: 99-108

Preston BL (2002) Indirect effects in aquatic ecotoxicology: implications for ecological risk assessment. Environ

Editorial responsibility: Søren Rysgaard,

Nuuk, Denmark
Manage 29:311-323

Shannon CE, Weaver W (1949) The mathematical theory of communication. University of Illinois Press, Urbana

Skei J, Larsson P, Rosenberg R, Jonsson P, Olsson M, Broman D (2000) Eutrophication and contaminants in aquatic ecosystems. Ambio 29:184-194

Skovhus TL, Ramsing NB, Holmstrom C, Kjelleberg S, Dahllof I (2004) Real-time quantitative PCR for assessment of abundance of Pseudoalteromonas species in marine samples. Appl Environ Microbiol 70:2373-2382

Smith D, Hughes RG, Cox EJ (1996) Predation of epipelic diatoms by the amphipod Corophium volutator and the polychaete Nereis diversicolor. Mar Ecol Prog Ser 145: 53-61

Strickland JD, Parsons TR (1972) A practical handbook of seawater analysis. Bull Fish Res Board Can 167

Sundbäck K, Snoeijs P (1991) Effects of nutrient enrichment on microalgal community composition in a coastal shallow-water sediment system-an experimental study. Bot Mar 34:341-358

Sundbäck K, Petersen DG, Dahllöf I, Larson F (2007) Combined nutrient-toxicant effects on a shallow-water marine sediment system: sensitivity and resilience of ecosystem functions. Mar Ecol Prog Ser 330:13-30

Taub FB (1997) Unique information contributed by multispecies systems: examples from the standardized aquatic microcosm. Ecol Appl 7:1103-1110

Underwood GJC, Phillips J, Saunders K (1998) Distribution of estuarine benthic diatom species along salinity and nutrient gradients. Eur J Phycol 33:173-183

Valsecchi G, Gigliotti C, Farini A (1955) Microbial biomass, activity, and organic-matter accumulation in soils contaminated with heavy-metals. Biol Fert Soil 20:253-259

Vinebrooke RD (2005) Do multiple stressors have additive or non-additive effects on aquatic ecosystems? In: Conference Abstracts of the ASLO summer meeting. ASLO, Santiago de Compostela, p 163

Vinebrooke RD, Cottingham KL, Norberg J, Scheffer M, Dodson SI, Maberly SC, Sommer U (2004) Impacts of multiple stressors on biodiversity and ecosystem functioning: the role of species co-tolerance. Oikos 104:451-457

Webb DG (1993) Effect of surface deposit-feeder (Macoma balthica L.) density on sedimentary chlorophyll a concentrations. J Exp Mar Biol Ecol 174:83

Wiegner TN, Seitzinger SP, Breitburg DL, Sanders JG (2003) The effects of multiple stressors on the balance between autotrophic and heterotrophic processes in an estuarine system. Estuaries 26:352-364

Williams SL, Ruckelshaws MH (1993) Effects of nitrogen availability and herbivory on eelgrass (Zostera marina) and epiphytes. Ecology 74:904-918

Wolters V, Silver WL, Bignell DE, Coleman DC and 14 others (2000) Effects of global changes on above- and belowground biodiversity in terrestrial ecosystems: implications for ecosystem functioning. BioScience 50:1089-1098

Worm B, Reusch TBH, Lotze HK (2000) In situ nutrient enrichment: methods for marine benthic ecology. Int Rev Hydrobiol 85:359-375

Submitted: November 21, 2006; Accepted: April 16, 2007 Proofs received from author(s): July 16, 2007 